\title{
Review of Emergency Radiological Instrumentation and Analytical Methods at NMSS-Licensee Sites
}

Prepared by W. N. Herrington, R. L. Kathren, J. L. Kenoyer, J. D. Jamison

Pacific Northwest Laboratory

Operated by

Battelle Memorial Institute

Prepared for

U.S. Nuclear Regulatory

Commission 


\section{NOTICE}

This report was prepared as an account of work sponsored by an agency of the United States Government. Neither the United States Government nor any agency thereof, or any of their employees, makes any warranty, expressed or implied, or assumes any legal liability of responsibility for any third party's use, or the results of such use, of any information, apparatus, product or process disclosed in this report, or represents that its use by such third party would not infringe privately owned rights.

\section{NOTICE}

\section{Availability of Reference Materials Cited in NRC Publications}

Most documents cited in NRC publications will be available from one of the following sources:

1. The NRC Public Document Room, 1717 H Street, N.W. Washington, DC 20555

2. The NRC/GPO Sales Program, U.S. Nuclear Regulatory Commission, Washington, DC 20555

3. The National Technical Information Service, Springfield, VA 22161

Although the listing that follows represents the majority of documents cited in NRC publications, it is not intended to be exhaustive.

Referenced documents available for inspection and copying for a fee from the NRC Public Document Room include NRC correspondence and internal NRC memoranda; NRC Office of inspection and Enforcement bulletins, circulars, information notices, inspection and investigation notices; Licensee Event Reports; vendor reports and correspondence; Commission papers; and applicant and licensee documents and correspondenze.

The following documents in the NUREG series are available for purchase from the NRC/GPO Sales Program: formal NRC staff and contractor reports, NRC-sponsored conference proceedings, and NRC booklets and brochures. Also available are Regulatory Guides, NRC regulations in the Code of Federal Regulations, and Nuclear Regulatory Commission /ssuances.

Documents available from the National Technical Information Service include NUREG series reports and technical reports prepared by other federal agencies and reports prepared by the Atomic Energy Commission, forerunner agency to the Nuclear Regulatory Commission.

Documents available from public and special technical libraries include all open literature items, such as books, journal and periodical articles, and transactions. Federal Register notices, federal and state legislation, and congressional reports can usually be obtained from these libraries.

Documents such as theses, dissertations, foreign reports and translations, and non-NRC conference proceedings are available for purchase from the organization sponsoring the publication cited.

Single copies of NRC draft reports are available free, to the extent of supply, upon written request to the Division of Technical Information and Document Control, U.S. Nuclear Regulatory Commission, Washington, DC 20555

Copies of industry codes and standards used in a substantive manner in the NRC regulatory process are maintained at the NRC Library, 7920 Norfolk Avenue, Bethesda, Maryland, and are available there for reference use by the public. Codes and standards are usually copyrighted and may be purchased from the originating organization or, if they are American National Standards, from the American National Standards Institute, 1430 Broadway. New York, NY 10018. 
NUREG/CR-2499

PNL-4163

\section{Review of Emergency Radiological Instrumentation and Analytical Methods at NMSS-Licensee Sites}

Manuscript Completed: May 1984

Date Published: August 1984

Prepared by

W. N. Herrington, R. L. Kathren, J. L. Kenoyer, J. D. Jamison

Pacific Northwest Laboratory

Richland, WA 99352

Prepared for

Division of Fuel Cycle and Material Safety

Office of Nuclear Material Safety and Safeguards

U.S. Nuclear Regulatory Commission

Washington, D.C. 20555

NRC FIN B2218 

This report provides a brief review of emergency radiological monitoring instrumentation capabilities based on visits to Nuclear Materiais Safety and Safeguards (NMSS) licensees and on a review of the open literature. Recommendations based on findings are made with regard to instrument design and operation, training, calibration, testing, analytical methods, sampling procedures, anc quality assurance. An assessment of currentiy available instrumentation is made with respect to types of instruments, instrument specifications, future needs of NRC/NMSS 7 icensees as seen by instrument manufacturers and extent to which those needs will be met. 



\section{CONTENTS}

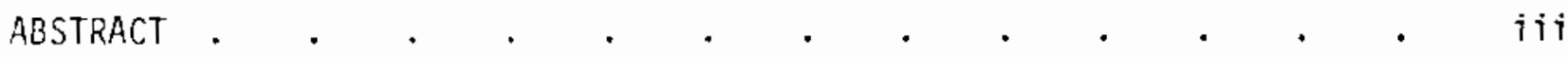

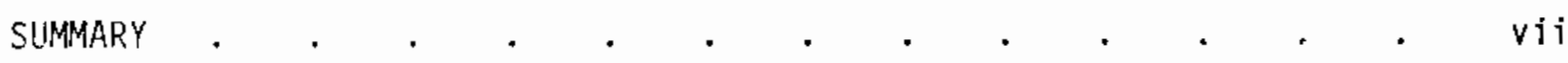

ACKNOWLEDGEMENT $\quad . \quad$. . . . . . . . . . . . . . . . . . . . .

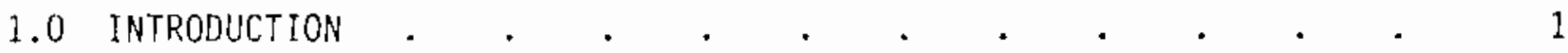

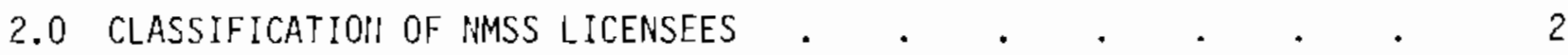

3.0 IMSTRLMENTATION SELECTION, SUITABILITY, AND TERMINCLOGY • . 6

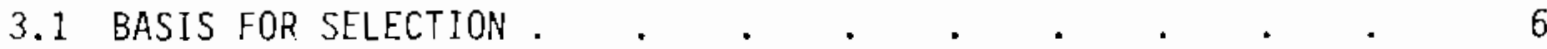

3.2 PRIOR WORK . . . . . . . . . . . . . 7

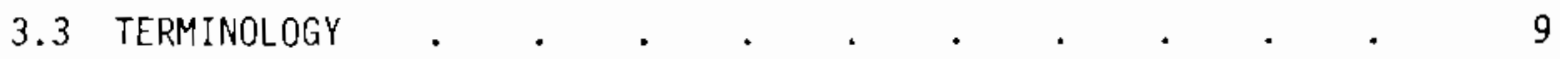

4.0 CLKRENT STATUS OF EMERGENCY INSTRUMENTATION AT LICENSEE

4.1 TRAINING . . . . . . . . . . . . . . . . 13

4.2 MAINTENANCE AND TESTING . . . . . . . . . . . . . . . . 13

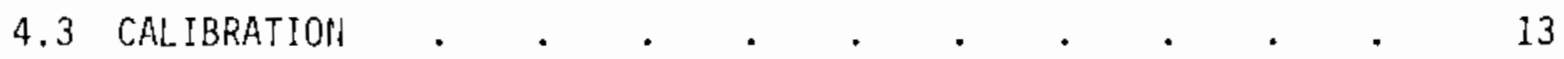

4.4 INTERPRETATION OF INSTRUMENT READINGS . . . . . . . 15

4.5 QUALITY ASSURANCE . . . . . . . . . . . . . . . . . 15

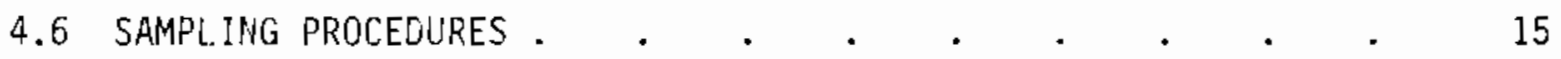

4.7 ANALYTICAL PROCEDURES . . . . . . . . . . . . 15

4.8 INSTRIMENT GUIDELINES . . . . . . . . . . . . . 16

4.9 EMERGENCY KITS . . . . . . . . . . . . . . . . . 16

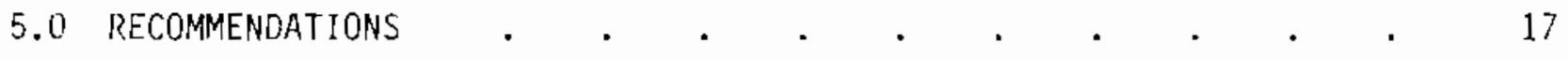

5.1 INSTRUMENT DESIGN, AND OPERATION $\quad . \quad \ldots \quad . \quad$. . . . 17

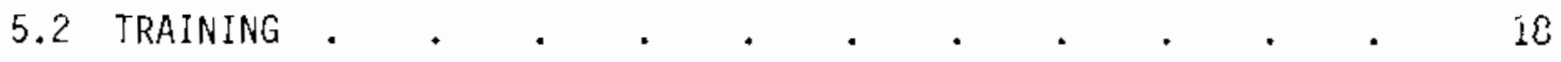

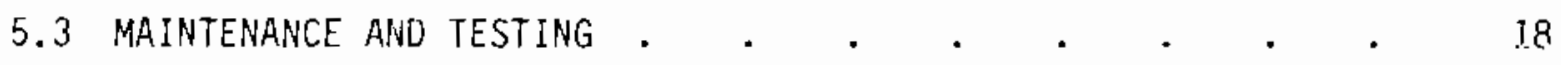

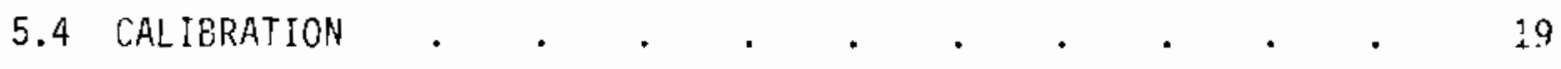




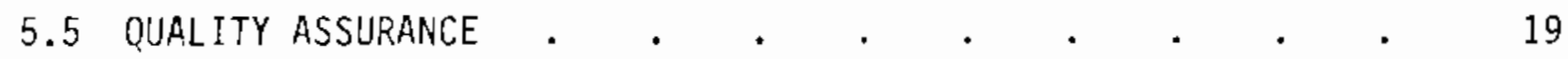

5.6 SAMPLING PROCEDURES . . . . . . . . . . . . . . . . . . 20

5.7 ANALYTICAL METHODS . . . . . . . . . . . . . . . . . 20

6.0 ASSESSMENT OF CURRENTLY AVAILABLE INSTRUMENTATION . . . . . . 2].

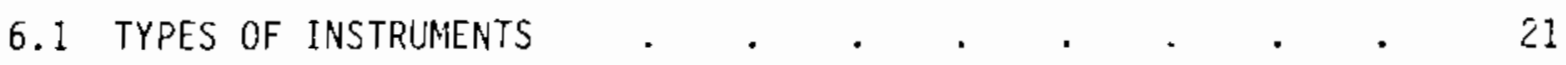

6.2 VENDOR INFORMATION ON CURRENT INSTRUMENTATION . . . . . 37

6.3 FUTURE INSTRUMENTATION NEEDS OF NRC/NMISS LICENSEES • • • 39

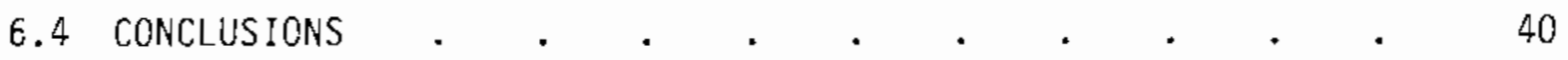

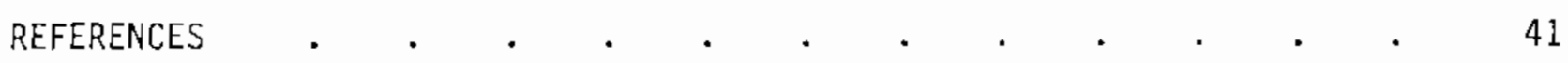

APPENDIX A - EXAMPLES OF SPECIFIC EQUIPMENT OBSERVED DURING SITE VISITS $\quad \cdot \quad \cdot \quad \cdot \quad \cdot \quad \cdot \quad \cdot \quad \cdot \quad \cdot \quad \cdot \quad \cdot \quad$ A.I

APPENDIX B - QUESTIONNAIRE SENT TO VENDORS AND MANUFACTURERS • • • B.l 


\section{SLMMARY}

Pacific Northwest Laboratory has conducted a review of emergency radiological monitoring instrumentation capabilities at Nuclear Materials Safety and Safeguards (NMSS) 7icensee sites and has made an assessment of currently availabie instrumentation.

The review of the emergency radiological monitoring instrumentation capabilities was based on visits to NMSS licensees and on a review of the open literature. Recommendations based on these site visits and open-literature review are made with respect to instrument design and operation, training, calibration, testing, analytical methods, sampling procedures, and quality assurance. The information obtained on commercial instrumentation currentiy available to NMSS licensees and other users was obtained through a questionnaire sent to manufacturers and vendors and by a review of commercial instrument catalogs. The assessment of currently available instrumentation is made with respect to types of instruments, instrument specifications, the future needs of NRC/NMSS licensees as seen by instrument manufacturers and the degree to which those needs will be met.

Instrumentation currently avaiTable and in use at NMSS licensees appears to provide adequate monitoring of potential radiological accident conditions. Generally, problems identified in the site visits were minor and pertained to the use and maintenance of emergency instrumentation, not inadequacies of the instruments themseives. The responses of manufacturers and vendors regarding future instrumentation needs of NRC/NMSS 7 icensees and the methods by which they will be met show that: 1) there are some manufacturers that are sensitive to or at least knowledgeabie of NRC/NMSS requirements and future needs, and 2) that sonie nianufacturers pian to improve or modify existing systems or to introduce completely new systems to meet those needs. Most of the improvements involve the incorporation of computerized systems for data analysis and control or new types of detectors. 



\section{ACKNOWLEDGEMENT}

The technical editing assistance of Mary Ann Mckinney is gratefuliy appreciated. 

REVIEW OF EMERGENCY RADIOLOGICAL INSTRUMENTATION

AND ANALYTICAL METHODS AT NMSS-LICENSEE SITES

\subsection{INTRODUCTION}

The atility of NMSS Ticense holders to carry out emergency radiological actioris depends largely on the instrumentation availabie to measure and assess the severity of an accident. To determine the adequacy of available emergency instrumentation and analytica? methods at NMSS licensee sites, the Nuclear Regulatory Commission (NRC) requested Pacific Northwest Laboratory (PNL) * to evaluate existirig emergency radiological instrumentation ana analytical procedures at selected licensee sites and to provide recommendations which, if ubserved, would ensure that emergency capabilities are not compromised by inadequate equipment.

The numbers and kinds of emergency instruments needed to ensure an adequate response level are a function of the radioactive materials inventory and types of operations performed at any given facjitity. The radiotoxicity and chemical form of the material, as well as the quantity and operations performed, varies widely among NMSS licensees. Thus, not all facilities have the same accident potential or projected radiological consequences, and differing ievels and types of energency instrumentation may be required to achieve a suitable capability.

The first phase of the study is directed towards categorizing NMSS licensees according to projected hazards from maximum credibie accidents (MCA) to provide a basis for generically determining the instrumentation capability required for adequate management of the emergency situation. An examination is also made of the capabilities of available state-of-the-art instrumentation and arialytical methods applicable to emergency conditions resulting from the MCAs.

The second phase of the study addresses the adequacy of available instrumentation and arialytical techniques, correlating this with various categories of licerised facilities previously developed. Deficiencies are identified aro chariges in procedures and instruments are suggested to correct the deficiencjes.

The final phase of the study assesses current comercially availabie instrumeritation with respect to types of instruments, instrument specifications, and the future needs of NRC/NMSS licensees as seen by instrument manufacturers and to what extert those needs will be met.

* Operated by Battelle Memorial Institute for the U.S. Department of Energy. 


\subsection{CLASSIFICATION OF NMSS LICENSEES}

Projected conditions resulting from an accident are highly variable because of the wide diversity in operations, the type and cuantity of radioactive materials, and site specific factors of NMSS licensees. This is often a source of confusion to both licensees and regulators in selecting instruments and analytical procedures for energency response. Since instrumentation needs will vary greatly from licensee to licensee, a classification system based on accident potentia? was developed for application to NMSS licensees to provide a common basis for determining emergency instrument needs.

Several characteristics are considered in the basis of classification, including:

- quantity of activity

- type and energy of radiations

- physical or chemical form of the radioactive materials

- specific types of operations involving radioactivity

- hazards potentialiy posed by the radionuclides.

Although the first four characteristics are essential to any scheme used as the basis for selection of radiological instruments, no single one is adequate in and of itself. For example, a system based solely upor quantity of activity does not consider the ability of the instruments to detect the particular type and energy of radiation; thus, if tritium were the nuclide in question, a typical Ceiger-Mueller (GM) portable survey meter using a thin metal wall tube would be useless, al though such an instrument might be useful for assessing the contamination hazards from beta emissions with higher energies such as $32 p$ or 90Sr-90y. Sinilarly, again assuming a tritium hazard, the chemical, e.g., oxide versus molecular) and physical (e.g., gas versus liquid) forms also need to be considered because these also affect instrument requirements. The type of operations (e.g., glove-box enclosure versus open hood) may determine other necessary instrument characteristics.

The ciassification system developed considers the first four characteristics in addition to the potential hazards of the specific radionuclides for which the license is issued. Thus, the emergency preparedness concept is evaluated holistically but with emphasis on the protection of the general public.

Once the basis for ciassification was defined, broad categories of NMSS 7 icensees were developed according to the measurement needs posed by projected MCA conditions. These are summarized in Table 2.1, which lists, for each of the categories developed, a key word description along with specific levels of dose rate and activity concentration that may be encouritered during postulated MCAs. This study was not concerned with accident scenarios, risks of accidents, or site specific MCAs, but rather with the medsurement and assessment of conditions created by the MCAs. The radiation and radioactivity concentration levels shown in Table 2.1 were derived from the largest possession limits in current NMSS licenses and should vary in direct proportion with changing possession 
TABLE 2.1. Categories of NMSS Licensees

\begin{tabular}{|c|c|c|}
\hline Category & Description & Parameters \\
\hline I & Criticality & $\begin{array}{l}\text { Fissile materials in } \\
\text { amounts sufficient to } \\
\text { support a chain } \\
\text { reaction }\end{array}$ \\
\hline I I & $\begin{array}{l}\text { High-hazard } \\
\text { high-Activity } \\
\text { airborne release }\end{array}$ & $\begin{array}{l}\text { Kilocurie plus amounts } \\
\text { of haiggens and noble } \\
\text { gases (fluid form and } \\
\text { particulate) (126I, } \\
131 \text { I, } 133 \times e, \alpha, B \text {, } \\
\text { r emitters) }\end{array}$ \\
\hline I I I & $\begin{array}{l}\text { Low-hazard high- } \\
\text { activity release }\end{array}$ & $\begin{array}{l}\text { Kilocurie amounts of } \\
\text { relatively low-energy } \\
\text { beta emitters }\left({ }^{3} \mathrm{H},\right. \\
\left.{ }^{4} \mathrm{C}, 32 \mathrm{P}\right)\end{array}$ \\
\hline IV & $\begin{array}{l}\text { External radiation } \\
\text { hazard }\end{array}$ & $\begin{array}{l}\text { High-activity sealed } \\
\text { sources }\left({ }^{60} \mathrm{Co},{ }^{137} \mathrm{Cs}\right)\end{array}$ \\
\hline
\end{tabular}

Emergency Levels/ Measurement Consideration

A) External photon dose rates up to several hundred $\mathrm{rad} / \mathrm{h}$

B) Airborne mixed fission products up to $5 \mathrm{ci} / \mathrm{m}^{3}$

C) Surface contamination (aipha) to $10^{6} \mathrm{dpm} / 100 \mathrm{~cm}^{2}$

A) Externai dose rates up to 100 $\mathrm{rad} / \mathrm{hr}$

B) Airborne concentrations of various radionuclides, including radioiodines, to $10 \mathrm{Ci} / \mathrm{m}^{3}$

A) External dose rate dependent on energy of radionucitide but not significant

B) Airborne concentrations, probably gaseous rather than particulate, to $50 \mathrm{Ci} / \mathrm{m}^{3}$

A) External photon dose rates to $10^{4} \mathrm{rad} / \mathrm{h}$

B) No airborne contribution unless source breached 
limits, assuming no change in operations or engineered controls. The levels given are upper limits and should be considered as such. With the exception of Category I, Criticality, the limits cited in the table may be one to several orciers of magnitude greater than those that would actually be incurred because of a smaller inventory of 1 icensed material.

Nearly all acute hazards will result from airborne radioactivity releases or direct penetration photon radiations. Surface contamination as from airborne fallout and liquid releases to stationary or moving bodies of water are unlikely to pose actual emergency monitoring probiens except pcssibiy in the case of an accidental criticality, which might scatter alpha-emitting fissile material of high radiotoxicity (e.g., ${ }^{239} \mathrm{Pu}$ ) outside the area in which external dose rates are of concern.

No single simple classification scheme can achieve unambiguous categorization; a few facilities will, of necessity, fall into mure than one category as they are large and diversified with potential for several types of accidents. In this case, the instrumentation shoula be adequate for conditions in each category in which the facility fits.

Category I facilities are those possessing fissile materials (239Pu, $233 \mathrm{U}$, $235 \mathrm{u}$ ) in quantities sufficient to support a self-sustaining chain reaction. A criticality accident may pose immediate life threatening or significant internal and external radiation hazards at both onsite and offsite locations. The yield of a criticality accident would be on the order of $10 i \% 2$ fissions, potentially capable of producing estinated airborne fission product concentrations of up to about $5 \mathrm{Ci} / \mathrm{m}^{3}$ beyond the focus of points at which a lethal dose would be incurred. Fission products confined to the immediate area of the event could produce exposure rates of several hundred $R / h$ or greater for a short time after termination of the fission chain reactior. Beta exposures in excess of $10^{4} \mathrm{rad} / \mathrm{h}$ might also be observed near the point of criticality. Hence, for lifesaving purposes, instrumentation with high-range capability will be required. However, a few hours post-accident, exposure rates should not exceed 50 or $100 \mathrm{R} / \mathrm{h}$.

Offsite concentrations of airborne activity could approach several curies per cubic meter, largely of short-lived chemically inert noble gases. Since these are beta emitters, they prinarily produce an external hazard from immersion in the cloud. However, significant quantities of radioiodines and radicstrontiums may aiso be releaseo to the environment, necessitating some measurement capability in this regard. In addition, alpha-emitting material may be volatilized or released in particulate form and plate out on surfaces outside the zone of external hazard. Thus, capability for monitoring alpha surface contamination and perhaps alpha air activity may be required.

An important capability for emergency assessment of a criticality accident is to identify and quantify specific nuclides. This is ordinarily accomplished by sampling and laboratory evaluation, usually by gamma spectroscopy. However, because accident dosimeters (foil activation devices) may need to be processed on an emergency basis, radioactivity counting equipment and pre-established procedures are required. 
Category II includes reprocessing facilities and source production/manufacturing sites with poteritial for large releases of both gaseous and particulate radioactivity. The latter could inciude transuranic elements, as well as fission products, and the former radioiodines and noble gases. Radianuclide concentrations near the point of release may be as great as $10 \mathrm{Ci} / \mathrm{m}^{3}$, with exposure rates to $100 \mathrm{~F} / \mathrm{h}$.

Category III facilities are those with the potential to release relativeiy large activities of low-energy beta emitters such as ${ }^{14} \mathrm{C}$ and ${ }^{3} \mathrm{H}$ to the atmosphere. Even a large release of radioactive material from facilities in this category would probably not pose actual health hazards but could result in exposures in excess of the maximum permitted for the general public. Air concentrations to $50 \mathrm{ci} / \mathrm{m}^{3}$ near the point of release are possible for low-energy, pure beta emitters such as $3 \mathrm{H}$, with the specific concentration largely dependent upon the quantity and form of the material and nature of the accident.

Category IV is composed primarily of facilities possessing high-activity sealed sources, including radiographers. Emergency consideration is not ordinarify required unless a source is ruptured or otherwise loses integrity; in this case, Category II applies. However, if a kilocurie activity scurce is lost or damaged or sticks in an open position, adverse health effects could be incurred as a resuit of exposure to high-level radiation fields. Photon radiation fieids of $10^{4} \mathrm{R} / \mathrm{h}$ or greater could require measurement. 


\subsection{INSTRUMENT SELECTION, SUITABILITY, AND TERMINOLOGY}

Knowledge of the nature and extent of the spectrum of potential emergencies is a mecessary prerequisite to selection of appropriate emergency instrumentation. Intelligent determination of the suitability of an instrument for emergency use also demands a certair degree of general knowledge regarding radiological measurements, as wel] as knowledge of the specific characteristics of the instrument. Therefore, this section was developed to provide a cohesive discussion of the technical bases on which emergency instrument selection should be made.

\subsection{BASIS FOR SELECTION}

In seiecting emergency instrumentation, the licensee should be able to answer the following questions:

- Does the instrument measure the appropriate radiation(s)?

- Does the instrument have a range of neasurement consistent with the accident potential of the facility?

- Is the instrumentatior system suitable for the conditions under which it rlay be used (e.g. outdoors in harsh winter environnients; in high humidities, etc.)?

- Do suitable numbers of instruments exist?

- Are suitable emergency analytical criteria and procedures available in addition to the instrumentation?

- Has the instrument been calibrated (and, ideally, evaluated) for Emergency levels and coriditions?

- Are personnel adequately trained and knowledgeable in emergency instrument use?

clearly, affirmative answers to these questions are required. The iicensee, perhaps assisted by the licensing agency and other outside experts, should attempt to ariswer the questions in the approximate order given, seeking an affirmative answer to each. The order is important in that the first three questions basically deal with the physical capabilities of the instruments, which, if suitable, may bear on the number required. The final three questions relate to operational aspects that are accomplished after the instruments have been acquired. For example, calibration needs and facilities may often be directly determined by the specific instrument(s) used; obviously, procedures and training are determined to a great extert by the specific instruments available. 


\subsection{PRIOR WORK}

Regrettably, although the literature relating to radiological emergencies and emergency planning is extensive, relatively little is pertinent to emergency instrumentation capabilities or is highly site specific. Thus, there exists no converient comprehensive and up-to-date guidance for the NMSS licensee or licensor. Laboratory counting and instrumentation and emergency analytical procedures are commonily ignored indicating that the need for research in this area is acute.

There is, however, some guidance available in the older literature that is applicable to the present day. Keene et al. (1963) prepared an excellent overview of emergency planning for radiation accidents and included consideration of emergency instrumentation requirements. Among the salient points made were these:

- Instruments for use in rescue operations shouid have capability to $5000 \mathrm{R} / \mathrm{h}$ or integration to $600 \mathrm{R}$.

- High-range emergency instruments may be provided through special purchase or by special detectors, shields, or other accessories that increase the range of routinely used monitoring instruments.

- Emergency instruments should maintain capability over extended periods of nonuse.

Other general guidance was provided by MCBride and Cunningham (1972).

Two other older works bear mention. The first is a paper by fish (1965) originally presented in 1963, that deals exclusively with dosimetry and instruments for radiological accidents. This work is succinct and, although dated, identifies many important aspects of emergency radiological instrumentation selection, use, and maintenance that might otherwise go unrecognized. Written as guidance "...to assist those responsible persons whose primary occupation is not that of a health physicist," it succeeds. It also might serve as the model for an updated regulatory guide or similar advisory.

The other is a paper by Kiefer and Maushart (1965) presented at a World Health Organization symposium that considered emergency radiological equipment needs. They noted five special requirements for emergency instrumentation: 1) measure higher doses than normal, 2) obtain results more quickly than usual, 3) make a larger number of measurements than usual, 4) carry out measurements in usual areas, in the open air, in cars, in trucks, or in provisional Taboratories, 5) use unskilled personnel for making measurements and taking samples. To these shoula be added the consideration of the potential use of the instruments, e.g., to evaluate the potential dose to those involved in rescue operations or in evacuating a populated area. These factors indicate a need for reliability and accuracy that might not otherwise be required.

Perhaps the most germane and extensive work is a study of emergency instrumentation preparedness performed by PNL under contract to the Atomic Energy 
Commission and, later, its successor agency, the Energy Research and Development Administration, during the early and middle 1970s. In the first phase of the work, performed in 1970, emergency instrumentation capabilities were examined at 33 sites, including 19 reactors and 11 Atonic Energy Commissior, facilities (Seiby and linruh 1971). This work revealed that:

- Instrumentation used for routine radiological measurerient should also be capable of providing suitable information in an emergency, but Tacks adequate range.

- Selection and piacement of instrumentation used for monitoring normal controlled releases does rot assure applicability to the emergency situation.

- Instrumentation and needs at power reactors viere not generally comparable to those at other facilities.

- Capabilities of continuous monituring instrumentation generally decreased with the accident potential of the facility.

Other phases of the study pruvided guidance on emergency instrumentation for reactors (Selby et al. 1973), mixed-oxide fuel-fabrication facilities (Andersen et a 1. 1972), fuel-reprocessirig plants (Aridersen et al. 1974), and energency instrumentation performance, evaluation, and calibration criteria (Bramson et a1. 1974). On the one hand, the latter study is particularly usetui in that it provides a comprehensive examination of emergency radiological instrument capabilities for field moritoring and sampling, but on the other hand, the capabilities and tests put forth may be beyond what is necessary at many NMSS-licensed facjlities, except perhaps for the larger fuel cycle activities. Moreover, it is doubtful that commercial instrumentation now available has been suitably evaluated for conformance with, or is even designed to meet, the performance criteria put forth by Bramson et al.(1976). Also, the work is essentially mute on counting laboratory instruments and emergency analytical procedures.

In addition to the PNL study, there are a few standards published by the American National Standaras Institute (ANSI) that have application, albeit 1 imited, to enlergency instrumentation at NMSS sites. These include ANSI N13.51972, which provides performance specifications for pocket dosineters and ANSI N323-1978, which does the same for radiation protection instruments (ANSI 1972; ANSI 1978b). In addition, ANSI N320-1979, specifically deals with emergency radiological monitoring instrumentation (ANSI 1979). Nithough this latter ANSI standard is specific to reactors, it generally applies to NMSS facilities (particulariy the larger ones) as well. The ANSI standards are at best only of peripheral applicability, as is also true of the Institute of Eiectrical and Electronic Engineers (IEEE) standards. Regulatory Guide 8.25 discusses the frequency of calibration, error limits for measurement of air sample volume, and documentation of calibration for routine and emergency air sampling programs (U.S. NRC 1980a).

Largely as a resuit of the accident at the Three Mile Island Nuclear Station, attention has been focused on reactor emergency instrumentation. Specific guidance for power reactors is provided by Regulatory Guide 1.97 (U.S. 
NRC 1981) and the compilation of Lahti et al. (1980) for various types of emergency monitoring instrumentatiors. Although specific to power reactors, some of the guidarice is applicable to NHSS licensees. More general guidance is provided by Schmidt (1978), who reported on the recommendations of the Federal Interagency Task Force on Offsite Energency Instrumentation. This work, while limited to monitoring in the environs following a major accident (as from a power reactor), is nonetheless largeiy applicable to potential accident situations at least at the larger NMSS-licensed facilities. NUREG-0654/FEMIA-REP-1, REvision I also discusses some of the emergency instrumentation needs for post-accident situations at nuclear power plants which may be applicable here (U.S. NRC 1980b).

The reliance of licensees on commercialiy avajiable instrumentation raises questions with regard to the adequacy of the instrumentation, both from the standpoint of performance and of meeting the needs of the licensee in the emergency situation. Evaluation of stated or claimed performance is still in its irifancy, and the user must cften rely on what information is provided by the manufacturer regarding performance. Then, too, the user may not be atle to clearly state or even understand needs or, if stated, to obtain the appropriate instrumentation. Indeed, the site visits revealed that, in general, little or no consideration is given to ruggedized instruments. For example, aithough portable survey instruments may be called upon to perform outdocrs in a variety of environmental conditions, there is frequently no provision made for waterproofing, low-temperature operation, operational checks (other than battery test), a seif-contained scalc or meter ilitumination, or various human factors.

\subsection{IERMIINOLOGY}

To provide unambiguous use of instrument termirology in the remainder of the report, this section gives a brief description of general instrument types and their more common use. These include sample analysis instrumentation, survey meters, remote-area monitors, and continuous-air monitors.

Instruments used for sample analysis (i.e., those used in the counting room to determine sample activity) include typical laboratory counting equipment and spectroscopy systeris of varying degrees of sophistication. The sample is usually a wipe of removable surface contamination or an air particulate filter, although liquid samples or others requiring radiochemical treatment prior to counting might also bi included.

Survey meters are small, hand-held, rate meters for mixed beta-photon, photons only, beta-alpha, or neutron radiations. Some may have dose or exposure integrating capability. Included with the survey meters are surface con tamination monitors, which are simpie count-rate instruments that provide a quick method of scanning equipment or personnel for radioactive material, and personal alarm dosimeters or detectors. These instruments are equipped with self-contained (i.e., battery) power supplies.

Remote-area monitors continually measure ambient radiation levels and provide an audible or visual signal when excernal radiation levels have exceeded a 
preset point. These are usually ac powered and are permanently located. Continuous-air monitors provide a continuous readout of airborne radioactivity concentrations and may also have solar capability. Air-samping devices are simply air-moving or channeling devices that draw air through a filter or other collecting medium for subsequent analysis. 


\subsection{CURRENT STATUS OF EMERGENCY INSTRUMENTATION AT LICENSEE SITES}

Several site visits were made to NMSS-1icensed facilities to gather firsthand information and to augment the limited amount of published material concerning analytical methods and instrumentation applicable to accident conditions. Selection of specific sites to visit was based on the desire to obtain a representative cross section of licensees, the funding and time constraints, and the willingness and cooperation of the licensee. Facilities with large radioactive material inventories were selected for two reasons. The first was to visit larger sites to maxinize the amount of information gained. The second reason is that, of the several thousand NRC materials licensees, only a few with the greatest licensed activity (i.e., those amount which could cause significant offsite doses), were required to maintain a formal emergency contingency plan, including emergency radiological instrumentation. Visits were made to two fabrication facilities, one Targe research institute, an isotope production facility, and a radioisctope storage/distribution center.

The licensees were asked open-ended questions that reflected primary interest in the following areas:

- radiological instruments presently used for sampling and sample analysis, field surveys (i.e., portable survey meters) and monitoring, including alarming instruments

- use of instruments or instrument readings to assess the nature and severity of an accident

- maintenance and calibration and

- other factors affecting instrument accuracy and the efficiency of anatytical response.

These subjects are considered in the following discussion.

The general types, applications, and measurenent ranges of observed instrumentation are Tisted in Table 4.1. Examples of specific instruments observed during the site visits and available commercially are given in Appendix $A$. An impressive variety of comercial instrument models and types was noted during the site visits. Instrument inventories were continuously upgraded and changed as new models become available; however, this may not be true for smaller licensees.

In general, when licensees bought commercial instrumentation, they did not take into account the instrument's specifjcations with regard to emergency use. Anticipated routine monitoring conditions were used for purchase specifications. Therefore, some of the currently used instruments were inadequate for the specific type of emergency situations that might be encountered. The choice of inadequate instruments may have also occurred due to the licensee handicap of receiving incomplete or inadequate specifications from the manufacturers and vendors of instrumentation. At present, there is a paucity of suitable instrumentation standards and guides for general application in the field. 
IABLE 4.1. General Instrument Types, Appifications, and Measurement Ranges

\section{Instrument Type}

A. Sample Analysis

(Analysis of wipe and air

filter samples)

B. Portable survey meters

(Determination of $B, Y$, neutron dose rate and $a, \beta^{-}, y$ surface concontamination)

C. Fixed monitoring/alarming (Determination of criticality events and abnormal radiation levels in an area)

\section{Applications}

1) Gamina spectroscopy systeris

2) Gas flow counters for $\alpha, \beta^{-}, Y$

3) Liquid scintiliation counters for low energy $\vec{B}$

1) Small voiume $\left(<50 \mathrm{~cm}^{3}\right)$ ion chambers, mostiy nonpressurized for high-rate fields

2) Medium-volume ion chambers for mixed $\beta^{-} / r$ radiations

3) Thin window GMs for contamination surveys

4) Gamma insensitive neutron rate meters.

1) Multiple ion chamber systeris for criticality monitoring (2 of li system, where minimum of 2 detector trips required for alarm)

2) Single ion chamber, GM, or scintiliatinc detector for other external y field alarmirig situations

3) Constant-flow a ir samplers for $\alpha, \beta^{-}$, airborne contaminants

4) Passive criticality monitors for postaccident evaluation (require laboratory evaluation).
Measurenient Ranges

Few $n \mathrm{C} i$ to several $\mathrm{mC} ;$

Tevel sample deperident upor background and geometry.

\section{Dose Rate \\ $0-10 R / h r\left(\beta^{-}, \gamma\right)$ \\ $0-20 \mathrm{R} / \mathrm{hr}$ (neutron)}

$\frac{\text { Contamination Leve } 1}{0-1.5 \times 10^{5} \mathrm{cpm}}$

$\left(\alpha, \beta^{-}, \gamma\right)$

$0-100 \mathrm{R} / \mathrm{hr}$ with

adiustable alarri

(lucal and remote, visual and audible alarms) 


\subsection{TRAINING}

Aithough all licensees visited gave a positive response to having personnel aofquately trained in the use of radiological instruments, only three of eight have established retraining programs. The remaining five gave informa? instructions on an infrequent and ad hoc basis. The quality of the training programs was not assessed. Two facilities ran annual drills simulating serious accidents to test existing emergency preparedness plans. Therefore, the researchers concluded that licensees generally assigned a low priority to personnel education and relied heavily upon incoming expertise or on-the-job trairing.

\subsection{MAINTENANCE AND TESTING}

A!? facilities reported a maintenance and testing program to some extent for radiation-detection arid measurement equipment. Half of the licensees required a periodic operations check of energency instrumentation at time intervals ranging from daily to semimonthly, while the remainder performed such checks infrequently or not at all. An operational check consists of obtaining a single-point, instrumert reference reading with an uncalibrated (i.e., nonreference or traceable) check source to ensure that the instrument is in faci responsive to radiation and is set at approximately the correct level. The physical condition of the iristrument should also be inspected and the power supply (if dc) tested.

The operational check supplements the periodic calibration and provides an extra degree of confidence that emergency monitoring equipment will be uperational when needed. Operational checks at intervals greater than quarterly are considered inadequate. Therefore, half the facilities visited were observed to be deficient in this area.

\subsection{CALIERATIUHA}

Determination of response cr readings of an instrument to a series of known radiation values over the range of the instrument (i.e., the caibration) is well established for routine analytical counting equipment. Most facilities calibrated against a llational Bureau of Standards (NBS) traceable source with an activity generally less than $1 \mu \mathrm{Ci}$. This may be satisfactory for monitoring routine operations of near background activity but is inadequate for analysis of high-activity samples expected during an accident. In many cases, the activity in accident samples were expected to exceed the measurement capability of iristruments used for routine analysis.

Most facilities planned to identify high-activity samples by using a scanning procedure that permits them to be isolated for special handling and analysis. Unfortunately, samples so identified were not assured of analys is with designated equipment or were to be analyzed after a significant alteration (e.g. changes in source to detector distance or change in shield configuration) in the physical setup of the system. This requires additional time and, most 
importantly, reflects abnormal or nonstandard operating procedures for which the 1 icensee was generally unprepared.

Calibration of portable survey meters and fjxed alarming monitors to accident level conditions created a special problem for the licensees because of the high dose rates involved. Most facilities chose to send high-rate instruments to a vendor for calibration, because of the convenience and to avoid the costs of high-level radiation facilities used only on an occasional basis. In addition, limiting radiation exposures to personnel was a consideration. A few facilities visited were capable of calibrating high-level or emergency monitoring instruments, at least from a physical facilities standpoint, while others expressed no concern for high-level calibrations.

Those facilities dependent upon a vendor to calibrate instruments were frequently aware of only one parameter involved in the calibration. Except for calibration enersy, little was known about the vendor's physical setup, how many points (or even if any) on each scale were checked, or whether the power supply or linear response was tested before calibration. Similarly, the response to radiation levels beyond the range of the instrument or the effects of such basic environmental variables as temperature and humidity were generally not known. Information on the parameters listed above is valuable to the licensee in determining if the calibration satisfies their needs.

The probiem was much the same with regard to air sampling and monitoring instrumentation. Air flow of the pumping device and the efficiency of the collecting medium are two critical parameters in air sampling (U.S. NRC 1980a). A rotameter was commonly used to calibrate vacuum pumps; other methods mentioned included in-line testing and multiple intercomparisons. Calibration was not normally accomplished under filter loading conditions, nor was an appraisal made of air in-leakage. Only three of the licensees visited actually determined filter efficiency. These used the "two filter method" in which filter efficiency was obtained from the ratio of sample counts from two inline filters. The remaining facilities either assumed $100 \%$ efficiency or relied upon published manufacturer's specifications.

The frequency of caibration for radiological equipment varied widely: licensees quoted periods of "daily," "monthly," "as used," and "as needed" for analytical instruments. Portable and fixed-monitoring instruments and air samplers were calibrated at semiannual or quarterly intervals as specified by license conditions. Other questions concerning calibration details triggered unanimous or nearly unanimous positive responses such as:

- Are instruments calibrated exactly as required by the licensee?

- Is the calibration energy approximately the same as that encountered in the field?

- Are instruments tagged with calibration dates and all pertinent information that affect readings?

- Are complete records kept for each calibration? 


\subsection{INTERPRETATION OF INSTRUMENT READINGS}

The facilities visited relied largely upon the past experience and training of the radiological safety staff to interpret portable radiological instrument readings. This subject was not observed in licensee procedures and existing training programs onty briefly mentioned this aspect of accident assessment.

Interpretation of fixed instrument readings was also observed to be deficient. Most licensees had calculated only one point of a release rate (such as from an instrument readout in $\mathrm{cpm}$ or $\mathrm{mR} / \mathrm{hr}$ to $\mu \mathrm{Cj} / \mathrm{sec}$ for a stack munitor), and that was the alarm point. The potential is therefore great that, if a stack release occurs, the magnitude of that release could not be determined in a timely manner. Most stated that, using instrumentation readout data, a calculation could eventualiy be performed to determine the amount of material released to the environment. The researchers doubted, however, that this calculation could have been completed in sufficient time to be of use in an energency.

\subsection{QUALITY ASSURANCE}

Vague answers were given to questions concerning the quality assurance (QA) of radiological instruments. Only half of the facilities visited reported ongoing QA programs. The others stated that they had infrequent or incomplete reviewing procedures. Several sites with estabijshed programs described rather extensive efforts to assure the quality of measurements. For exampie, two facilities reported that all daily operations were reviewed by computer to assure that records and instrument calibrations are current.

\subsection{SAMPLING PROCEDURES}

Most of the facilities visited had predetermined routes between sampling points and the location of analysis to avoid loss of samples and sample contamination. While this should be useful for both routine operations and emergency response, again, littie consideration appears to have been given to the high-activity levels associated with accidents, including the increased likelihood of sample cross-contamination with increasing activity and the possibility of contaminating the ccunting equipment. In exireme cases, some samples may require shielding or special handing to avoid cross-contamination, increased background in counters, and personnel exposures. These precautions were generally not addressed in sampling procedures.

\subsection{ANALYTICAL PROCEDUIRES}

Licensees expected to use the same analytical procedures for acciderit evaluation as those currently used for routine monitoring. However, since most analytical equipment is designed and calibrated to measure low levels of radioactivity, samples taken under accident conditions may exceed the maximum measureable activity for fixed geometry conditions. Apparently, licensees had 
not considered the magnitudes of activity and the attendant handing and analytical probiems that might be encountered in a post-accident situation.

\subsection{INSTRUMENT GUIDELINES}

Hait of the licensees interviewed had established operational guidelines for analytica? instruments. These were step-by-step ("cookbock") instructions for sample analysis. The others relied on instrument maruals to supply basic or supplemental information. Some facilities relied exclusiveiy upon one or two technicians for all sample analysis. Thus, in the case where no guidelines existed and the techniciar was not present, the aralyses could not be performed.

Instructions for operation of portable survey meters, remote area monitors, and air samplers were sometimes found in the licensing file at some facilities. In general this information was rot easily or conveniently accessible, nor in fact very useful for answering questions on specific instruments because the information was rot pertinent to the proper use of the instrument. In no case did emergency instrumentation operation guidelines specifically address all necessary aspects of emergency use. The guidelines were largely broad-bush treatments of linited value.

\subsection{EMERGENCY KITS}

All facilities either had an tmergency kit or quick access to emergency equipment such as protective clothing, NOISH-approved respirators, flashijghts, and communications equipment. The adequacy of the kits was variable but generally satisfactory. 


\subsection{RECOMMENDATYONS}

Assessment of the current accident monitoring status at selected NMSS sites, coupied with a review of commercially avajlable instrumentation, as described in the manufacturer's literature, revealed several areas of weakness and led to the development of the recommendations discussed in this section. It sholid be borne in wind that the recommendations are, of necessity, generic rather than specific to the needs of a small number of 1 icensees. However, the transition of applicability to any individual licensee should be apparent and relativeiy easily accomplished. This does not mean that the recommendaticrs are simplistic or superficial; rather, in some cases, they are quite deep and require a combined effort on the part of the licensees, regulatory bodies, and instrumient manufacturers for implementation.

\subsection{INSTRUMENT DESIGN AND OPERATION}

Perhaps the single most important improvement in the emergency instrumentation area would be the establishment of basic criteria, in the form of a suitable standard, regulatory guide, or other advisory document, to guide licensees, manufacturers and regulators with regard to emergency instrumentation and procedures. Such clidance could readily be prepared using the cornprehensive work of Fish (1965), Bramson et al. (1976), and others as a basis. Instrumentation: ierformance should be verified as meeting the established criteria through actual testing and evaluation. A riechanism such as an independtent testing and evaluation laboratory leading to certification of performance might also prove desirable.

In addition to development of hasic criteria and instrument performance tvaluations, which may be a relatively long-term generic solution to many problems, certain design and other changes can be implemented on a specific ad hoc basis by individual manufacturers, including:

- improved resolution of portabie single and muitichannel analyzers

- improved sensitivity and human factors engineering of portabit monitors for gasecus low-energy beta emitters (e.g., ${ }^{14} \mathrm{CO}_{2},{ }^{3} \mathrm{H}$ )

- internal audit circuitry and battery test capability cin portable dcpowered units

- ruggedizing (e.g., shock mounting, weatherproofing) of instruments to permit survival of operability under extreme post-accident conditions ... this applies to both field and laboratory instruments, for the latter niay be required to operate continuously and in uncontrolled atmospheres

- more detailed specifications, instructicrs, and troubleshooting information in instrument manuals, along with actual measurement and verification of capability rather than reliance on theory or extrapolation from less demanding conditions. 


\subsection{TRAINING}

Ongoing training -- both formal and informal -- is needed for all employees, and especially for those participating in a facility's response team.

This is particularly true for those select few charged with the responsibjlity for sample analysis and fielo riecsurements in the event of an emergency. For each work shift, an adequate number of trained personnel should be available to cover all onsite and offsite locations of interest. In addition, at least one and preferably two persons trained in the operation of anaiytical instruments should be available cn short notice.

A successful training program is one that provides and maintains the individual's familiarity with high-range instrument operation and specific emergency assignments. Training intervals not exceeding one year are usualiy sufficient, especialiy if an emergency drill is included. Designated personne? should be instructed particularly in any changes in geometry, instrument settings, and technique that may be required for accident level conditions, and should also have the opportunity to make practice use of the instruments they may be called upon to use. Training is also valuable as a tool to identify problems and allow for correction prior to an emergency.

Interpretation of instrument readings has a direct influence upon measurement accuracy and should be thoroughly addressed in the training program. Training for personnel who may be called upon to use emergency radiological measurements should cover all significant points that could directly affect enid results of monitoring efforts. For portable rate meters, this includes instrument orientation, self-shielding effects, angular dependence, energy dependence, tracking error, switching effects, response time and environmental effects.

\subsection{MAINTENANCE AND TESTING}

New radiological monitoring equipment should be tested to the extent possible when delivered to verify that manufacturing, regulatory, and licensee specifications are met. Descriptions of suggested test and calibration methods for instrumentation may be found in the reference iisting at the end of this report. Severa? of the more important tests (e.g. linearity response) should also be performed on a continuing basis to assure proper operation. Emergency-designated equipment should be checked for response before each use and on a monthly or quarterly basis.

The following technique or one similar to it may be used for testing instrument response. Shortly after calibration of radiological equipment, a check source may be used to obtain a reference reading. This source can then be used to check the instrument response on a periodic basis. Variation of more than $25 \%$ in subsequent checks under identical conditions suggest the instrument is out of calibration or malfunctioning. 


\subsection{CALIBRATION}

Accurate analys is of high-activity samples on an instrument calibrated for near background levels is tenuous at best. If source strength is excessive, dead time or resolution losses may be great and render the low-level calibration inapplicabie. For a calibration to be valid, the test source should approximate the type and intensity of the radiation to be measured in the field. If high-level sources are used, special techniques and physical facilities may be required, and care shouid be exercised to assure that frequent use of the source does not violate good ALARA practices, degrade the detectors, or produce contamination problems. Calibration sources should be traceable to NBS for energency as well as routine analyses. Appropriate or suitable NBS standards, however, are not always available and it may be necessary to obtain calibrations with norirelatable laboratory standards.

The frequency of calibration for emergency operations will vary according to the type and use (including storage or standby operation) of the instruments. A change of source-detector geometry may be required in laboratory instruments for the high-ievel analyses associated with an emergency. The effects of the altered source to detector distance, dead-time losses, and backscatter need to be considered along with other factors affecting the detector response. A careful calibration of activity as a function of count rate should be made for each designated emergency instrument. This also applies to portable monitoring instruments, except that for these instruments, calibration intervals may be less frequent.

Since the interpretation of field readings may depend on firsthand knowledge of the calibration setup, this information must be available. Ali faciljties having designated emergency response instruments calibrated by a vendor should document in detail the caljbration procedures used, including any precalibration checks performed, a description of the physical setup (source and instrument orientation), specifics on radiation type and energy used, and the points calibrated on each scale. For exposure and dose rate instrumentation, the calibration procedure should include exposure beyond the upper range to ensure that saturation or paralysis does not render the instrument unsuitable for emergency work.

\subsection{QUALITY ASSURAICE}

Quality assurance requirements for emergency instrumentation and procedures are similar and no less stringent than those imposed on normal operations. Procedures need to be written, reviewed and approved in accordance with established $Q A$ requirements. Accurate and complete records of all maintenance activities, including calibrations, are vital and could be of retrospective value, including legal protection. These records should allow traceability of the activities to accepted facility standards. Finally, a periodic review must exist to assure that routine maintenance activities, calibrations, and written procedures are current. 


\subsection{SAMPLING PROCEDURES}

Sampies taken for analysis should be representative of what actually exists in the field situation. Serious problems may arise from either inaction or overreaction in emergency response caused by ronrepresentative saniples. To the greatest extent possible, sampling procedures should be staridardized for a particular facility and printed in a "cookbook" forrat.

High-activity samples are a potential scurce of personnei exposure and should be treated as any other unsealed millicurie source. If background permits, sampies nay be scanned with a contamination monitor to isolate those showing high ieveis. Small, shielded containers may be used, but care must be taken to avoid cross-contaminatiur.

\subsection{ANALYTICAL METHODS}

Procedures for analytical methods should be established before any situation arises that requires their use. A predetermined route of anatysis should be designed, including all steps between sampling and final calculation. These should be prepared in the form of written procedure's that are easily understood by those who may use them. Procedures should be readily alajlable and maintained current. Procedures should call out the location of instruments, reagents, and other items that are referenced or specified.

An increase in the background radiation may be caused by a Jarge release of activity ard may compromise iow- or intermediate-level measurements. This possibility cannot be eliminated, but certain preventative steps can be taken to reduce the extent of contamination. It is not always reasonable or cunvenient to locate analytical equifnent distant from radionuclide operations. However, the relative locations of the two should not be such that a direct pathway exists between the areas of radionuclide usage and analytical equipment. Certain positive acticns such as sealing windows and doors and halting HVAC operations in the analytical areas during a release should be considered by the licensee. Of course, analytical equipment located in a building where Targe quantities of materials are stored should always be placed upstream (airfiow) of the materials. 


\subsection{ASSESSMENT OF CURRENTLY AVAILABLE INSTRUMENTATION}

Nicst studies on the application of radiologicai instrumentation concentrate on either routine usage or monitoring of power reactor accidents. Little information is availabie concerning instrumentation adequacies for accident situations at NMSS-licersed sites. The first part of this report discussed the instrumentation and procedures that a representative sampling of NMSS licensees would use during response to accidents. This section discusses state-of-theart instrumentaticr, that is currently available or that could be developed by the manufacturers to meet the needs of high-level or post-accident sampiing. Instrumentation specifications claimed by manufacturers and vendors are stated and future instrumentation reeds of NRC/NMSS licensees as seen by some manufacturers and vendors äre discussed.

\subsection{TYPES OF INSTRUMENTS}

Instrument requirements of MMSS-licensed sites vary tremendously. However, the level of NMSS emergency monitoring is expected to fall in the range from routine radiological monitoring at materials' sites, to accident-level monitoring at nuclear power generating stations.

Many types of radiological irstruments are used in inaustry today; however, only a few general types are of interest to this study. The foilowing categories of instruments were considered important in assessing accidents at MisS-licensed facilities:

- medium to high-range portable exposure and dose rate meters

- Tow to medium-range portable exposure and dose räte meters and contaminatiun survey meters

- facility area, process, and criticality monitors

- continuous air monitors

- dir samplers

- analytical equipment

- portable neutron monitors

- pertal monitors and hand and shoe moritors

- environmental radiation monjtors.

0ther types of instruments and devices may be used to aid in accident assessment (e.g., meteorological equipment, dosimetry), but these fali outside the scope of this study. The instrument types listed above were considered basic to most NifSS emergency response needs. 
No distinction between onsite and offsite instrumentation was made in this report. Onsite instrumentation may require ranges that are orders of magnitude greater than offsite devices. All other instrument capabilities should be similar, including the ability to operate in outdoor environments. This ability is necessary for onsite instruments because of the high potential for losing building-controlled environment capability (e.g. fire or loss of offsite power) during an accident.

\subsubsection{Medium to High-Range Portable Exposure and Dose Rate Meters}

NMSS 1 icensees use portable instruments such as those described in Table 6.l to determine medium to high-level beta-photon dose rates (i.e., 0.1 to $1000 \mathrm{rad} / \mathrm{h})$. The detector normally used for this task is an ion chamber. Several instrument manufacturers and vendors distribute GM type detectors claimed to accurately measure exposure and/or dose rates. Some of these units are designed to measure very high exposure rates. Most GM detectors have a very large energy dependence over the energy range of $40 \mathrm{keV}$ to $2 \mathrm{MeV}$ and, in aodition, are usualiy not very accurate or reliable in higher radiation fields. However, if the exposure conditions in which the instruments are to be used is known (e.g., exposure rates, nuclides, and radiation to be present), the instruments can be designed and calibrated to provide accurate readings. In general, ion chambers are nore reliable and accurate for wide-range applications.

\subsubsection{Low to Medium-Range Portable Exposure and Dose Rate Meters and Contamination Survey Meters}

Instruments that measure lower-ievel radiation fields (i.e., 0.1 to $1000 \mathrm{mrad} / \mathrm{h})$ and surface contamination $(0-80 \mathrm{~K} \mathrm{cpm})$, are shown in Table 6.2. Devices using scintillators and gas-proportional detectors are also useful. Caution should be exercised when using GM detectors; several factors will affect the capability of the instruments to provide useful and accurate readings. The upper dose rate limit of many GM-type instruments is considerably below $1000 \mathrm{mrad} / \mathrm{h}$ and may be even lower than $1 \mathrm{mrad} / \mathrm{h}$. As mentioned in the preceding section on medium to high-range instruments, $G M$ detectors have a large photon energy dependence. Also, on the lower ranges of most GM detectors, the precision (i.e., the repeatability) of the measurements can be very poor. Instruments will aiso have different response times for different ranges, therefore, entry into unknown radiation fieids must be perfomed carefully and scanning rates of contaminated surfaces modified accordingly.

\subsubsection{Facility Area, Process, and Criticality Monitors}

The monitors shown in Table 6.3 are used to alert personnel and, in sone cases, to quantify abnormal radiological conditions. Devices included in this category are area, process, criticality, and stack monitors, which will most often be the device used to detect and quantify releases to the environient. For these instruments, the monitoring point is normally placed downstream from the last material confinement barrier. An ion chamber is the most common type of detector although some devices use GM detectors. The definite advantage of an ion chamber is that it can be used in higher radiation fields without satura tion of the detector response. Most monitors are equipped with remote readouts and visual and audible alarms. 
TABIE 6.1. Medium to High-Range Portable Exposure Rate Meters

\begin{tabular}{|c|c|c|c|c|c|c|c|c|c|}
\hline Manufacturer & Model & Detector & \multicolumn{3}{|c|}{$\begin{array}{l}\text { Radiations } \\
\text { Detected }\end{array}$} & Range & \multirow[t]{2}{*}{ Accuracy } & $\begin{array}{c}\text { Energy } \\
\text { Dependence }\end{array}$ & \multirow[t]{2}{*}{ Scale } \\
\hline Berthold & TOL/E, LB 1310 & $1 C^{*}$ & $x$ & $x$ & $x$ & $\begin{array}{l}0-3 \mathrm{KR} / \mathrm{h} \\
0-300 \mathrm{R} \\
\text { integration }\end{array}$ & & $\begin{array}{l} \pm 100 \text { from } 10 \mathrm{KeV} \\
\text { to Co- } 60\end{array}$ & \\
\hline Eberline & $\mathrm{RO}-2, \mathrm{RO}-2 \mathrm{~A}$ & $1 \mathrm{C}$ & & $x$ & $x$ & $0-50 \mathrm{R} / \mathrm{h}$ & & $\begin{array}{l} \pm 10 \text { from } 20 \mathrm{KeV} \\
\text { to Co- } 60\end{array}$ & Linear \\
\hline Eberline & $R 0-3 C, R O-3 D$ & IC & & $x$ & $x$ & $0-100 \mathrm{R} / \mathrm{h}$ & & $\begin{array}{l} \pm 10 \text { from } 10 \mathrm{KeV} \\
\text { to } 1 \mathrm{MeV}\end{array}$ & Linear \\
\hline Eberline & $R 0-7$ & IC & & $x$ & $x$ & $\begin{array}{l}0.1 .9 \mathrm{R} / \mathrm{h} \\
0-100.0 \mathrm{R} / \mathrm{h} \\
0-19.99 \mathrm{KR} / \mathrm{h}\end{array}$ & & & DigitaT \\
\hline Eberline & PIC. $-6 A$ & 10 & & $x$ & $x$ & $\begin{array}{l}\text { t mR/h to } \\
1000 \mathrm{R} / \mathrm{h}\end{array}$ & & & $\log$ \\
\hline Eberline & $6112 B$ & IC & & & $x$ & $0-1000 \mathrm{R} / \mathrm{h}$ & & & $\log$ \\
\hline Eberline & $6112 D$ & 16 & & & $x$ & $0-1000 \mathrm{R} / \mathrm{h}$ & & & Digital \\
\hline Jordan & $\begin{array}{l}\text { Radector } 1 \\
\text { ACB-500B-SR }\end{array}$ & 10 & & $x$ & $x$ & $\begin{array}{l}0.5 \mathrm{mR} / \mathrm{h} \text { to } \\
500 \mathrm{R} / \mathrm{h}\end{array}$ & \pm 208 & $\begin{array}{l}\text { Independent over } \\
\text { range } 80 \mathrm{KeV} \text { to } \\
1.2 \mathrm{MeV}\end{array}$ & $\log$ \\
\hline Jordan & $\begin{array}{l}\text { Radector III } \\
A C B=100-S R\end{array}$ & IC & & $x$ & $x$ & $\begin{array}{l}0.1 \mathrm{mR} / \mathrm{h} \text { to } \\
1000 \mathrm{R} / \mathrm{h}\end{array}$ & \pm 208 & $\begin{array}{l} \pm 158 \\
80 \mathrm{KeV} \text { to } 1.2 \mathrm{MeV}\end{array}$ & $\log$ \\
\hline Jordar: & $\begin{array}{l}\text { Radgun } \\
\text { ACB-1CKC-SR }\end{array}$ & IC & & $x$ & $x$ & $\begin{array}{l}0.05 \mathrm{mR} / \mathrm{h} \text { to } \\
10 \mathrm{R} / \mathrm{h}\end{array}$ & \pm 208 & $\begin{array}{l}\text { Independent } \\
80 \mathrm{Kev} \text { to } 1.2 \mathrm{MeV}\end{array}$ & $\log$ \\
\hline Keithiey & 36100 & ic & & $x$ & $x$ & $0-20 \mathrm{R} / \mathrm{h}$ & & $\begin{array}{l} \pm 10 \% \text { from } \\
12 \mathrm{KeV} \text { to } 2 \mathrm{MeV}\end{array}$ & Digital \\
\hline Ludl um & 77 & $\mathrm{Cr}^{* \pi t}$ & & & $x$ & $0-1 K R / h$ & & & $\log$ \\
\hline Ludl um & 17 & IC & & & $x$ & $0-50 \mathrm{R} / \mathrm{h}$ & & & \\
\hline $\begin{array}{l}\text { Technical } \\
\text { Associates }\end{array}$ & $C P-44$ & $1 \mathrm{C}$ & $x$ & $x$ & $x$ & $0-25 \mathrm{R} / \mathrm{h}$ & $\pm 5 \%$ & & Linear \\
\hline $\begin{array}{l}\text { Technical } \\
\text { Associates }\end{array}$ & $\begin{array}{l}\text { CP5 } \\
\text { Mark III }\end{array}$ & IC & & $x$ & $x$ & $0-250 \mathrm{R} / \mathrm{h}$ & $\pm 15 \%$ & & Linear \\
\hline Victoreen & $\begin{array}{l}470 \mathrm{~A} \\
\text { Panoramic }\end{array}$ & ic & & $x$ & $x$ & $0-1000 \mathrm{R} / \mathrm{h}$ & $\pm 10 \%$ & $\begin{array}{l} \pm 158 \\
10 \mathrm{KeV} \text { to } 2 \mathrm{MeV}\end{array}$ & Linear \\
\hline
\end{tabular}

* IC - Ion Chamber

** CM - Ceiger Muelier Detector 
TABLE 6.1. (cont)

\begin{tabular}{|c|c|c|c|c|c|c|c|c|c|}
\hline Manufacturer & Model & Detector & $\begin{array}{c}\mathrm{Ra} \\
\mathrm{D} \\
\underline{\mathrm{a}} \\
\end{array}$ & $\begin{array}{c}\text { iati } \\
\text { tect } \\
\text { S }\end{array}$ & & Range & Accuracy & $\begin{array}{c}\text { Energy } \\
\text { Dependence } \\
\end{array}$ & Scale \\
\hline Victoreen & 471 & IC & $x$ & $x$ & $\mathrm{x}$ & $0-300 \mathrm{R} / \mathrm{h}$ & $\pm 10^{8}$ & $\begin{array}{l} \pm 10 \% \\
6 \mathrm{~K} \in \mathrm{V} \text { to } 2 \mathrm{MeV}\end{array}$ & Linear \\
\hline Victoreen & $\begin{array}{l}740 \mathrm{~F} \\
\text { Cutie Pie }\end{array}$ & IC & $x$ & $x$ & $x$ & $0-25 \mathrm{R} / \mathrm{h}$ & \pm 108 & $\begin{array}{l} \pm 158 \\
40 \mathrm{KeV} \text { to } 2 \mathrm{MeV}\end{array}$ & Linear \\
\hline Xetex & $302 \mathrm{~B}$ & $G M$ & & & $x$ & $\begin{array}{l}0.01 \text { to } 1000 \\
R / h\end{array}$ & \pm 158 & $\begin{array}{l} \pm 15 \% \\
70 \mathrm{KeV} \text { to } 1.3 \mathrm{MeV}\end{array}$ & Digital \\
\hline
\end{tabular}


TABLF 6.2. Low to Mediur Rirlye Portable Exposure Rate and Contamination Survey Meters

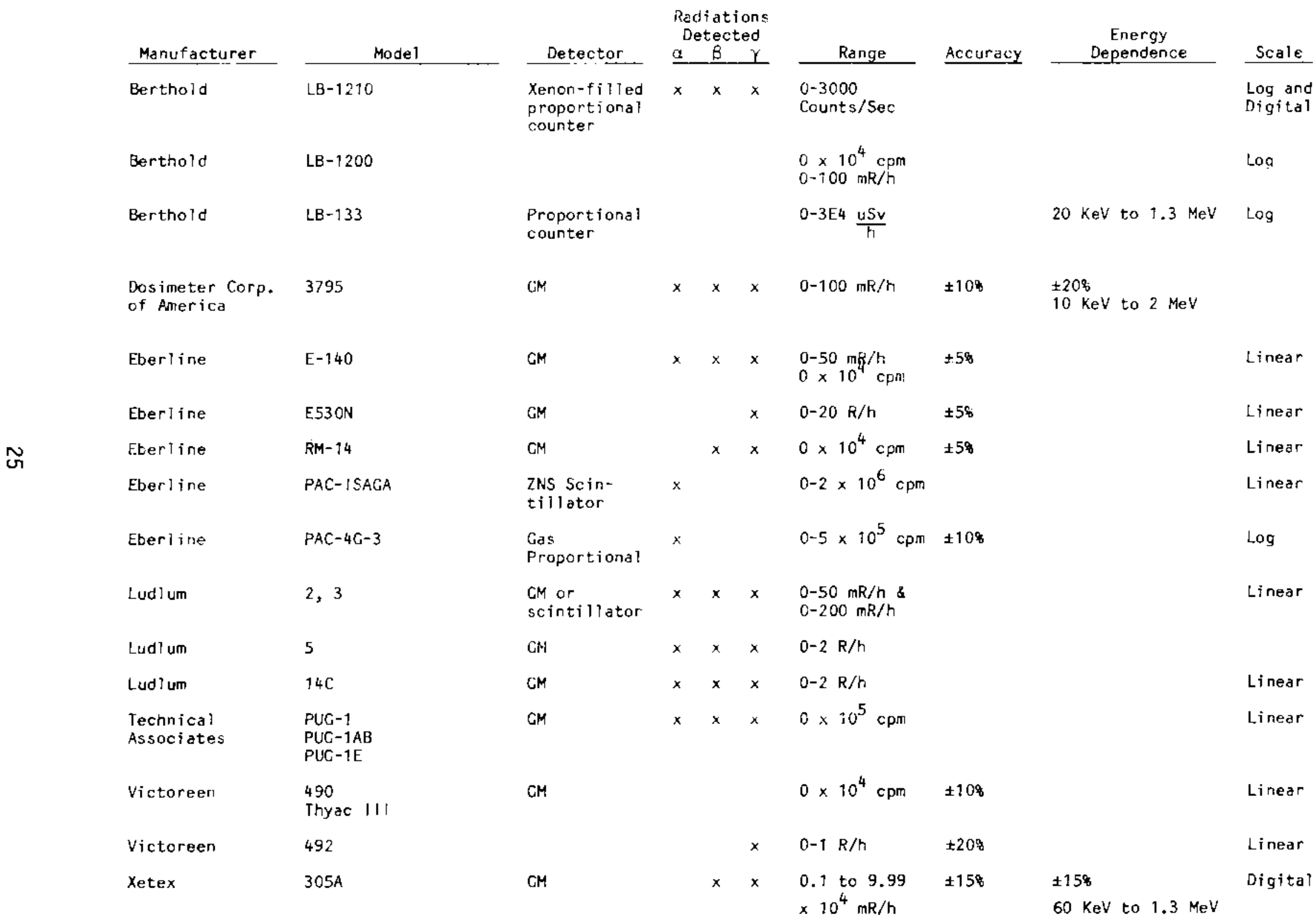


TABLE 6.3. Facility Area, Process, and Criticality Monitors

\begin{tabular}{|c|c|c|c|c|c|c|}
\hline Manuf acturer & Model & Detecter & Range _- & Accurary & Supply & Scale \\
\hline Eberline & $E C_{4}-x$ & GM and IC & $\begin{array}{l}0.01 \mathrm{mR} / \mathrm{h} \text { to } \\
10 \mathrm{KR} / \mathrm{h}\end{array}$ & Visual and Audible & $A C$ & Linear \\
\hline Eberline & $R M-14$ & GM & $0.5 \times 10^{4} \mathrm{cpm}$ & Visual and Audible & $A C / D C$ & Linear \\
\hline Eberline & $R H-20$ & $\mathrm{CM}$ & $0-5 \times 10^{4} \mathrm{cpm}$ & Visual and Audible & $A C / D C$ & Linear \\
\hline Eberline & $R M-21$ & $\mathrm{CH}$ & $\begin{array}{l}10^{1}-10^{6} \mathrm{cpm} \\
1-10^{4} \mathrm{mR} / \mathrm{h}\end{array}$ & Visual and Audible & $A C / D C$ & $\log$ \\
\hline CA Technology & GA "6-PAC" & $1 \mathrm{C}$ & $10^{1}-10^{4} \mathrm{R} / \mathrm{h}$ & Yes, Output & $A C$ & \\
\hline GA Technology & $R S-2 A$ & IC & $10^{1}-10^{4} \mathrm{R} / \mathrm{h}$ & Yes & $A C$ & \\
\hline GA Technology & RS-2D & IC & $10^{1} \cdot 10^{4} \mathrm{R} / \mathrm{h}$ & Yes & $A C$ & \\
\hline jordan & RAMP-IV & IC & $\begin{array}{l}1 \mathrm{mR} / \mathrm{h} \text { to } \\
1000 \mathrm{R} / \mathrm{h}\end{array}$ & & $A C$ & \\
\hline Ludl um & 177 & $\begin{array}{l}\mathrm{CH} \text { or } \\
\text { Scintillation }\end{array}$ & $0-5 \times 10^{5} \mathrm{cpm}$ & $\begin{array}{l}\text { Audible, Visual, } \\
\text { and Adjustable }\end{array}$ & $A C / D C$ & Linear \\
\hline Ludl um & 300 & $\mathrm{CH}$ & $0.1-1000 \mathrm{mR} / \mathrm{h}$ & $\begin{array}{l}\text { Audible, Visual, } \\
\text { and Adjustable }\end{array}$ & $A C / D C$ & $\log$ \\
\hline \multirow[t]{2}{*}{$\begin{array}{l}\text { Nuclear } \\
\text { Measurement } \\
\text { Corporation }\end{array}$} & $N M-6$ & $\begin{array}{l}\text { Moderated } \\
\text { B- } 10 \text { phosphor } \\
\text { for neutrons }\end{array}$ & $\uparrow-10^{5} \mathrm{mR} / \mathrm{h}$ & Audible and Visual & $A C$ & $\log$ \\
\hline & NM-6M & $\begin{array}{l}\text { Fioderated } \\
\text { 8- } 10 \text { phosphor } \\
\text { for neutrons }\end{array}$ & $1-10^{5} \mathrm{n} / \mathrm{R} / \mathrm{h}$ & Audible and Visual & $A C$ & $\log$ \\
\hline \multirow{2}{*}{$\begin{array}{l}\text { Nuciear } \\
\text { Measurement } \\
\text { Corporation }\end{array}$} & $G A-6 M$ & Scintillator & $0.1-10^{4} \mathrm{mR} / \mathrm{h}$ & Visual and Audíble & $A C$ & $\log$ \\
\hline & $\mathrm{GA}-6$ & Scintillator & $1-10^{5} \mathrm{mR} / \mathrm{h}$ & Visual and Audible & $A C$ & $\log$ \\
\hline \multirow{3}{*}{$\begin{array}{l}\text { Nuclear } \\
\text { Research } \\
\text { Corporation }\end{array}$} & AR-2 & GM & $10-10^{6} \mathrm{cpm}$ & Visual & $A C$ & $\log$ \\
\hline & ORM-100 & $\mathrm{GM}$ & & Visuat and Audible & $A C$ & Digital \\
\hline & $T A-90 A$ & $\mathrm{CM}$ & $0.1-10^{4} \mathrm{mR} / \mathrm{h}$ & Visual and Audible & $A C$ & $\log$ \\
\hline \multirow{2}{*}{$\begin{array}{l}\text { Techrical } \\
\text { Associates }\end{array}$} & $H A-2 A$ & $\mathrm{CM}$ & $0.1-1 R / h$ & Audible and Visual & $\mathrm{AC}$ & \\
\hline & FML & CM & $\begin{array}{l}0.01 \mathrm{mR} / \mathrm{h} \text { to } \\
10 \mathrm{R} / \mathrm{h}\end{array}$ & Audible and Visua? & $A C$ & \\
\hline
\end{tabular}


TABLE 6.3. (cont)

\begin{tabular}{|c|c|c|c|c|c|c|}
\hline Manufacturer & Mode] & Detector & Range & Accuracy & Supply & Scale \\
\hline Victoreen & $808 D$ & GM & $0.01-10 \mathrm{R} / \mathrm{h}$ & Audible and Visual & $A C$ & \\
\hline Victoreen & 845 & iC & $\begin{array}{l}0.1 \text { to } 10^{7} \\
\mathrm{mR} / \mathrm{hr}\end{array}$ & Audible and Visual & $A C$ & $\log$ \\
\hline Victoreen & 855 & 1C & $\begin{array}{l}0.01 \text { to } 10^{4} \\
\mathrm{mR} / \mathrm{hr}\end{array}$ & Audible and Visual & $A C$ & $\log$ \\
\hline
\end{tabular}




\subsubsection{Continuous Air Monitors}

Continuous air monitors (CAMs) are used to determine the concentration of radicactive air contaminants at specific facility locations. Monitors of this type are described in Table 6.4. CAM units can be used to determine: 1) gaseous radioactivity, 2) particulate radioactivity, 3) or radioiodine concentraticns. In some cases they also alert personnel to abrorma? radiological conditions. Some systems car rieasure these three different classifications of radioactivity simultaneousiy. Visual and audible alarms and remote readouts are available for many units.

Gaseous radioactivity monitors, continuously or at set tine intervals, sample quantities of air and measure the radioactivity present in the gaseous state. Such instruments are usually flow-through ionization chambers which are continuously flushed with air. Unless appropriate precautions are taken, flow-through and similar type gaseous monitors will also measure radioactivity present in or on solid particles suspended in air, and will also respond to ambient externa? radiation fields. In general, gaseous radioactivity monitors are most useful for radionuclides such as the noble gases where the limiting concentration is related to external dose from beta ensission, and for low energy beta emitters such as ${ }^{3 / 4}$ and ${ }^{14} \mathrm{C}$ which are internally hazardous. Gaseous radioactivity monitors should be equipped with filters to remove interfererices from particulate radioactivity, and they nust operate in tields $\geq 0.1$ $\mathrm{mrad} / \mathrm{h}$, without adverse effects on measurement capability.

Particulate radioactivity monitors measure only the radioactivity present in or on particulates suspended in ambient air. They filter or remove the particulates from a measured volume of dir, and continuously or periodicality measure the radioactivity in the material removed. Most CAM units draw air through a moving paper filter or a fixed fitter that is monitored with a radiation detection device.

Monitoring of radioiodines may be accomplished in a variety of ways, but consideration must be given to the chemical and physical state of the radioiodine. The applicability of the instrument for molecular iodine, methyl iodide, and particulate iodines needs to be considered. Some radioiodine monitors incorporate the use of activated charcoal filters and others use silver zeolite cartridges to capture the radioiodine for determination of radioactivity levels present.

\subsubsection{Portable Air Samplers}

Portable air samplers (described in Table 6.5) can be used to obtain samples of air contaminants at locations where continuous air monitors are not available or when accurate nieasurements are required. The sampling determines radiuactive iodine, gas, and particuiate concentrations in unsite and offsite locations. Samples are normally analyzed at a centralized or remote counting facility that is equipped with high-resolution analytical instrumentation. 
TABLE 6.4. Continuous Air Monitors

\begin{tabular}{|c|c|c|c|c|c|c|c|}
\hline Manufacturer & Mode? & Eetector & $\begin{array}{c}\text { Radiations/ } \\
\text { Radionuclides } \\
\text { Detected } \\
\end{array}$ & Range & Alarm & Recorder & $\begin{array}{c}\text { Filter } \\
\text { Coilection }\end{array}$ \\
\hline Berthold & LB 1068 & Proportional & $3_{i f}$ & $\begin{array}{l}10=8^{\text {of }} 1.75 \times \\
10^{5} / \mathrm{m}^{3} \\
1 \text { minute }\end{array}$ & No & Printer & Ho \\
\hline Eberline & $A X M-1$ & $\mathrm{CM}$ & $\begin{array}{l}\text { Particulates, } \\
\text { lodines, } \\
\text { Noble gases }\end{array}$ & $\begin{array}{ll}10^{2} \mu \mathrm{Ci} / \mathrm{cc} & \text { i } \\
10^{5} \mu \mathrm{i} / \mathrm{cc} & \mathrm{Xe}\end{array}$ & & & $\begin{array}{l}\text { Particulate } \\
\text { and lodine }\end{array}$ \\
\hline Eberline & $1 m-1$ & Scinti!lation & lodines & & Visual, Audible & Chart & $\begin{array}{l}\text { TEDA } \\
\text { Charcoal }\end{array}$ \\
\hline Eberline & $P \mid N C-1 A$ & Scintillation & $\begin{array}{l}\text { Particulates, } \\
\text { lodines, } \\
\text { Noble Cases }\end{array}$ & $10-10^{6} \mathrm{cpm}$ & Visual, Audible & Chart & $\begin{array}{l}\text { TEDA Char- } \\
\text { Coal and } \\
\text { Millipore }\end{array}$ \\
\hline Eberline & $P \mid N C-3$ & Seintillation & $\begin{array}{l}\text { Fariiculates, } \\
\text { lodines, } \\
\text { Noble Cases }\end{array}$ & & & Printer & $\begin{array}{l}\text { TEDA Char- } \\
\text { coaT and } \\
\text { Millipore }\end{array}$ \\
\hline Eberline & SPING -4 & $\begin{array}{l}B^{-} \text {scintiliator, } \\
\alpha \text { solid state, } \\
G M\end{array}$ & $\begin{array}{l}\text { Particulates, } \\
\text { lodines, } \\
\text { Noble gases }\end{array}$ & & Visual, Audible & $\begin{array}{l}\text { Remote } \\
\text { recorder } \\
\text { and } \\
\text { readout }\end{array}$ & $\begin{array}{l}\text { Particulate } \\
\text { and lodine }\end{array}$ \\
\hline Eberline & AMS -3 & $\mathrm{GM}$ & $B \quad a$ & $10-10^{5} \mathrm{cpm}$ & Audible, Visuat & Chart & Yes \\
\hline Eberline & ALPHA-5A & Solid state & $\beta \quad \alpha$ & $1-10^{3} \mathrm{cpm}$ & Audible, Visual & Chart & Yes \\
\hline CA Tech. & $R S-58 D$ & Scintillation & $\begin{array}{l}\text { Particulates } \\
\text { and lodines }\end{array}$ & & Yes & No & $v_{e s}$ \\
\hline CA Tech. & $\mathrm{RS}-52 \mathrm{D}$ & Scintiliation & $\mathrm{B}^{-}>150 \mathrm{KeV}$ & $\begin{array}{l}6 \times 10^{-8} \\
\text { to } \\
6 \times 10^{-2} \mu \mathrm{C}+/ \mathrm{cc}\end{array}$ & Visual, Audible & & $\begin{array}{l}\text { Particulate } \\
\text { and lodine }\end{array}$ \\
\hline GA Tech. & RS-60D & Scintillation & $\begin{array}{l}\text { Particulates, } \\
\text { lodines, and } \\
\text { Noble Gases }\end{array}$ & & Yes & No & Yes \\
\hline \multirow[t]{3}{*}{ Johnston Labs } & $955 \mathrm{~B}$ & IC & $\cdots$ & $0.05-50 \mathrm{mR} / \mathrm{h}$ & Audible & No & No \\
\hline & & & ${ }^{3} \mathrm{H}$ & $0-10^{3} \mu \mathrm{Ci} / \mathrm{m}^{3}$ & & & \\
\hline & & & ${ }^{14} \mathrm{C} \quad--$ & $0-2 \times 10^{3} \mu \mathrm{Ci} / \mathrm{m}^{3}$ & & & \\
\hline Johnston Labs & 117 & IC & $\mathrm{H}^{3}$ & $0-10^{6} \mu \mathrm{Ci} / \mathrm{m}^{3}$ & Visual, Audible & No & No \\
\hline Johnston Labs & $133 \mathrm{C}$ & IC & ${ }^{133} \times e$ & $0.0-100$ mpc & Visual, Audible & Chart & Particulate \\
\hline
\end{tabular}


TABLE 6.4. (cont)

\begin{tabular}{|c|c|c|c|c|c|c|c|}
\hline Manufacturer & Mode I & Detector & $\begin{array}{c}\text { Radiations/ } \\
\text { Radionuclides } \\
\text { Detected } \\
\end{array}$ & Range & Alarm & Recorder & $\begin{array}{c}\text { Filter } \\
\text { Collection } \\
\end{array}$ \\
\hline $\begin{array}{l}\text { Nuclear } \\
\text { Measurement } \\
\text { Corporation }\end{array}$ & $\begin{array}{ll}A M-22 & B F \\
A M-33 & B F \\
A M-22 & I F \\
A M-33 & I F\end{array}$ & $\begin{array}{l}\beta^{-} \text {Scintillator } \\
\text { and Nal crystal }\end{array}$ & $\alpha, \beta^{-}, Y$ & $50-5 \times 10^{4} \mathrm{cpm}$ & Visual, Audible & $\begin{array}{l}3 \text { Channel } \\
\text { Chart } \\
\text { Recorder }\end{array}$ & $\begin{array}{l}\text { Paper for } \\
\text { particulate } \\
\text { Silver zeo- } \\
\text { lite or Act. } \\
\text { Charcoal } \\
\text { for lodine }\end{array}$ \\
\hline $\begin{array}{l}\text { Technical } \\
\text { Associates }\end{array}$ & $F M-5-A B N I$ & Scintillator & lodines & $0-5 \times 10^{5} \mathrm{cpm}$ & Visual, Audible & $\begin{array}{l}\text { Chart } \\
\text { Recorder }\end{array}$ & $\begin{array}{l}\text { Silver } \\
\text { Activated } \\
\text { Charcoal }\end{array}$ \\
\hline Victoreen & ARPIGS-1 & Various & $\begin{array}{l}\text { Particulates } \\
\text { and lodines }\end{array}$ & $0-10^{2} \mu \mathrm{Ci} / \mathrm{cc}$ & $\begin{array}{l}\text { Connected to rem } \\
\text { readouts and ala }\end{array}$ & & $\begin{array}{l}\text { Separate } \\
\text { lodine and } \\
\text { Particulate } \\
\text { Filters }\end{array}$ \\
\hline Victoreen & WRGEM - I & Various & $\begin{array}{l}\text { Noble Gases } \\
\text { Optional } \\
\text { lodines and } \\
\text { Particulates }\end{array}$ & $10^{-7}-10^{5} \mu \mathrm{Ci} / \mathrm{cc}$ & $\begin{array}{l}\text { Connected to rem } \\
\text { readouts and ala }\end{array}$ & & Optional \\
\hline
\end{tabular}


TABLE 6.5. Portable Air Samplers

\begin{tabular}{|c|c|c|c|c|}
\hline Manufacturer & Mode 1 & Flow Rate & $\begin{array}{c}\text { Flow } \\
\text { Indicator } \\
\end{array}$ & Adjustable Flow \\
\hline Eberline & PAS -1 & $\begin{array}{l}\text { Dependent on } \\
\text { Intake Pressure }\end{array}$ & Yes & Yes \\
\hline Eberline & RAS-2 & $\begin{array}{l}\text { Dependent on } \\
\text { Intake Pressure }\end{array}$ & Yes & Yes \\
\hline Victoreen & $08-030$ & $30 \mathrm{~L} / \mathrm{m}$ & Yes & Yes \\
\hline $\mathrm{Hi}-\mathrm{Q}$ Environ. & $\begin{array}{l}C F-900 \mathrm{~V} \text { and } \\
\text { CF-950V }\end{array}$ & $2-40$ CFM & Yes & Yes \\
\hline $\mathrm{Hi}-\mathrm{Q}$ Environ. & $C F-50 \mathrm{~V}$ & $2-10$ CFM & Yes & Yes \\
\hline Hj-Q Environ. & STAPLEX & $0-70 \mathrm{CFM}$ & Yes & Yes \\
\hline Hi-Q Environ. & $C F-12 B$ & $\begin{array}{l}3-4 \text { CFM }(12 V D C) \\
7-8 \text { CFM }\end{array}$ & Yes & No \\
\hline $\mathrm{Hi}-\mathrm{Q}$ Environ. & $C F-18 \mathrm{~V}$ & $0-6$ CFM & Yes & Yes \\
\hline
\end{tabular}




\subsubsection{Analytical Equipmerit}

Analysis of wipe samples, bioassay samples, air samples, and stack samples may be necessary to make accident assessments. This requires equipment capable of accurately analyzing samples over a wide range of contaminaticn levels in a relatively short period of time. Examples of this type of instrumentation are given in Table 6.6. Specific counting systems may consist of gas proportioral counters with $2 \pi$ or $4 \pi$ geometry or $\mathrm{NaI}(\mathrm{TI})$, GeLi detectors or surface tarrier detectors with multichannel analyzers and assocjated electronics. Other spectrometers, medical dose calibrators, and iquid scintillation counters are often used. Samples may require dilution or partitioning before analysis in order to reduce the activity of the sample. High-level counting systems miay require special geometries or collimation with appropriate calibration to accomodate high counting rates. Currently availatle data analysis systeris include computers with appropriate software to reduce counting data into the desired format. The appropriate analytical techniques (e.g., chemical separation, particle filtration, spectrum stripping), are recessary tc icentify specific isotopes within a sample.

\subsubsection{Purtable Neutron Monitors}

Portable neutron moniturs are necessary only when fissile material or neutron sources are present. Currently available, state-of-the-art neutron monitors that claim to accurately measure neutron dose equivalent rate or dose equivalent are described in Tabie 6.7. Measurements made with differerit instruments must be interpreted very carefuily. The energy dependence, radiation detection efficiency, photon rejection, and angular dependence of the instrument, as well as the exposure conditions present (e.g., neutron energies, interfering radiations, location of radiaticn source) must be known before the instrument readings can be interpreced correctly or reliably. Generaily, exposure conditions are not known before entering the radiation area and the reddings of avajlable instruments may be misleacing.

\subsubsection{Portal Monitors and Hand and Shoe Monitors}

This group of instrumentation does not assist in direct acciderit assessment. However, it is important in the assessment of persomel contamination and control of cortamination during and after an accidtent. These types of inonitors may also double as area monitors which irdicate the presence of airborne radioactivity. Examples of this type of monitor are given in Table 6.8.

\subsubsection{Environmental Radiation Monitors}

Environmental radiation monitors are useful in deternining radiological conditions at offsite locations. A 7 ist of enviromental radiation monitors is given in Table 6.9. These instruments normally record the radiaticn dose rate from beta-photon radiation at a specific location over preselected time intervals. Offsite doses may be calculated from this record. Some monitors are equipped with telemetry and provide instantaneous readouts of remote radiological conditions back to the site. Most, however, require personal attention to collect monitoring data. 
TAELE_6.6. Analytical Equipment

\begin{tabular}{|c|c|c|c|c|c|c|}
\hline \multirow[b]{2}{*}{ Manufacturer } & \multirow[b]{2}{*}{ Mode? } & & \multicolumn{3}{|c|}{$\begin{array}{l}\text { Radiations } \\
\text { Detected }\end{array}$} & \multirow[b]{2}{*}{ Range } \\
\hline & & Detector & $\alpha$ & $B$ & $\gamma$ & \\
\hline Baird & $\begin{array}{l}\text { Centicount } \\
987-514\end{array}$ & Gas Flow & $x$ & $x$ & $x$ & $0-999,999$ Counts \\
\hline Baira & Polyspec & Gas Flow, GM, NaI & $x$ & $x$ & $x$ & $0-999,999$ Courits \\
\hline \multirow[t]{2}{*}{$\begin{array}{l}\text { Nuclear Measuremerits } \\
\text { Corporation }\end{array}$} & $P C-5, P C-55$ & $\begin{array}{l}\text { Gas Flow, } \\
\text { Scintilletion, GM }\end{array}$ & $x$ & $x$ & $x$ & $0-999,999$ Counts \\
\hline & ACS -7 & $\begin{array}{l}\text { Gas Flow, } \\
\text { Scintillation, GM }\end{array}$ & $x$ & $x$ & $x$ & \\
\hline Technical Associates & MST-202 & $\begin{array}{l}\text { Gas Frow, } \\
\text { Scintillation, GM }\end{array}$ & $x$ & $x$ & $x$ & \\
\hline Tennelec & LB 5100 & Gas Flow & $x$ & $x$ & $x$ & \\
\hline Ludlum & 2600 & $\begin{array}{l}\text { Proportional, GM, } \\
\text { Scintitlation }\end{array}$ & $x$ & $x$ & $x$ & $0-999,999$ Courts \\
\hline
\end{tabular}




\section{TABLE 6.7. Portable Neutron Monitors}

\begin{tabular}{|c|c|c|c|c|c|c|c|}
\hline Manufacturer & Mode? & Detector & $\begin{array}{l}\text { Ganina } \\
\text { Insen. }\end{array}$ & Range & Accuracy & Energy & Weight \\
\hline Ludlum & 15 & $\mathrm{BF}_{3}$ and $\mathrm{GM}$ & $10 \mathrm{R} / \mathrm{h}$ & $\begin{array}{l}0-5 \times 10^{5} \\
c p m\end{array}$ & & & $7.51 \mathrm{~b}$ \\
\hline $\begin{array}{l}\text { Nuclear } \\
\text { Research } \\
\text { Corporation } \\
\text { and } \\
\text { Victoreen }\end{array}$ & $\begin{array}{l}\text { Snoopy } \\
\text { NP-2 }\end{array}$ & $\mathrm{BF}_{3}$ & to $500 \mathrm{R} / \mathrm{h}$ & $0-2 \mathrm{R} / \mathrm{h}$ & $\begin{array}{l} \pm 10 \% \text { of theoretical } \\
\text { dose rate }\end{array}$ & $\begin{array}{l}\text { Thermal } \\
\text { to } 15 \mathrm{MeV}\end{array}$ & $25 \mathrm{lb}$ \\
\hline Victoreen & $488 \mathrm{~A}$ & $\begin{array}{l}\text { Boron-lined } \\
\text { proportional } \\
\text { counter }\end{array}$ & $<500 \mathrm{R} / \mathrm{h}$ & $\begin{array}{l}0-8 \times 10^{5} \\
\mathrm{cpm}\end{array}$ & $\pm 10 \%$ & $\begin{array}{l}\text { Thermal } \\
\text { to fast }\end{array}$ & $8.5 \mathrm{ib}$ \\
\hline
\end{tabular}


TABLE G.B. Portal Monitors and Hand and Shoe Monitors

\begin{tabular}{|c|c|c|c|c|c|c|}
\hline \multirow[b]{2}{*}{ Manufacturer } & \multirow[b]{2}{*}{ Model } & \multicolumn{4}{|c|}{$\begin{array}{l}\text { Radiations } \\
\text { Detected }\end{array}$} & \multirow[b]{2}{*}{$M D L$} \\
\hline & & Detector & $\underline{\alpha}$ & $\beta$ & $y$ & \\
\hline Berthold & LB 1044 & $\begin{array}{l}\text { Gas Flow } \\
\text { Proportional }\end{array}$ & & $x$ & $x$ & $\begin{array}{l}5.5 \mathrm{E}-{ }^{6} \mu \mathrm{Ci} / \mathrm{cm}^{2} \\
\left({ }^{60} \mathrm{CO}, 204 \mathrm{Tl},\right. \\
90 \mathrm{Sr})\end{array}$ \\
\hline Eberline* & PCM-1 & $\begin{array}{l}\text { Gas Flow } \\
\text { Proportional }\end{array}$ & & $x$ & $x$ & $\begin{array}{l}0.1 \mathrm{nCi} \\
(90 \mathrm{Sr}-90 \mathrm{Y})\end{array}$ \\
\hline LudTum & 50 & GM & & $x$ & $x$ & \\
\hline Ludlum* & 40 & GM & & $x$ & $x$ & \\
\hline Ludlum* & 50 & GM & & $x$ & $x$ & \\
\hline $\begin{array}{l}\text { Technical } \\
\text { Associates }\end{array}$ & $\begin{array}{l}\text { PPM } 21 \\
\text { PPM } 21 \mathrm{~A}\end{array}$ & GM & & $x$ & $x$ & \\
\hline $\begin{array}{l}\text { Technical } \\
\text { Associates }\end{array}$ & $\begin{array}{l}\text { PPM-23, PPM-23P } \\
\text { PFM-23GF } \\
\text { PPM-25, PPM-25P } \\
\text { PPM-25GF }\end{array}$ & $\begin{array}{l}\text { GM and } \\
\text { Gas Flow } \\
\text { Proportiona } 1 \\
\text { Counters }\end{array}$ & & $x$ & $x$ & \\
\hline $\begin{array}{l}\text { Technical } \\
\text { Associates }\end{array}$ & $\begin{array}{l}\text { HSM-10A } \\
\text { HSM-10AM } \\
\text { HSM-1DB } \\
\text { HSM-10BS }\end{array}$ & GM & $x$ & $x$ & $x$ & \\
\hline Technjcal & HSM-10G & $\begin{array}{l}\text { Gas Flow } \\
\text { Proportional } \\
\text { Counter }\end{array}$ & $x$ & $x$ & $x$ & \\
\hline
\end{tabular}

* Denotes hand and shoe monitor. 
TABLE 6.9. Environmental Radiation Monitors

\begin{tabular}{|c|c|c|c|c|c|}
\hline \multirow[b]{2}{*}{ Manufacturer } & \multirow[b]{2}{*}{ Model } & & \multicolumn{2}{|c|}{$\begin{array}{l}\text { Radiations } \\
\text { [etected }\end{array}$} & \multirow[b]{2}{*}{ Range } \\
\hline & & Detector & $\alpha$ & $e^{-} \ldots r$ & \\
\hline Eberline & $E M-1$ & & & & $0-100 \mathrm{R} / \mathrm{h}$ \\
\hline Reuter/Stokes & RSS-111 & IC & & $x$ & \\
\hline Reuter/Stokes & RSS $-111-100$ & IC & & & $1 \mu \mathrm{R} / \mathrm{h}$ to $100 \mathrm{mR} / \mathrm{h}$ \\
\hline Reuter/Stokes & RSS -1012 & IC & & $x$ & $1 \mu \mathrm{R} / \mathrm{h}$ to $10 \mathrm{R} / \mathrm{h}$ \\
\hline
\end{tabular}




\subsection{VENDOR INFORMATION ON CURRENT INSTRUMENTATION}

Information on specifications of currently available comercial instrumentation is discussed in this section. This information was obtained through a questionnaire sent to 25 radiaticr detection instrument manufacturers and vendors and by a review of commercial instrument catalogs available to the genera? public. A copy of this questionnaire is included in this report as Appendix B. Approxinately $50 \%$ of the manufacturers and vendors responded to the questionnaire after foliow-up contacts were made.

Data was obtaired on instrumentation currently available from a crosssection of manufacturers and vendors. Contacts were made with large and small instrument companies, and companies that specialize in one or two specific types of detectors, as well as or manufacturers that distribute a variety of instrumerits. The information obtained, though not intended to be ail iriclusive, should be considered as a thorough cross-section of manufacturers and vendors.

A general description of currently available instrumentation and their capabilities is found in Table 6.10. This listing is for comparison with Table 4.1, which describes the capabilities of instruments currertly in use at MMSS-1icensed sites. As can be seen, mayimum ranges differ by an order of magritude in some cases.

This difference does not necessarily indicate a deficiency at NMSSlicensed sites. The meximum ranges listed in Table 6.10 correspond to instruments designed for abnormial power reactor monitoring. Regulation Guide 1.97 (U.S. NRC 1981) provides instrument vendors with an incentive to upgrade effiuent and area monitors for power reactor applications. This is fortunate because many of the upgraded niodels may be adaptable to materials licensee use.

It riust be pointed out, however, that of the sites observed none identified the need for instruments with such extreme high ranges. The capabilities of the instruments currently available and currently in use appeared adequate for monitoring, either directly or indirectly, the accident condition listed in Table 2.I. Problems ider.tifjed in this study were generaliy minor and involved the use and maintenance of emergency instrumentation rather than instrument inadequacies. Recommendations for improved instrument lise and maintenance are Tisted in Section 5.0.

Data on specific instrumentation was summarized in Tables 6.1 through 6.9 of this report. Information was $T$ isted for different instruments under the categories of medium to high-range portable exposure and dose rate meters, low to medium-range portable exposure and dose rate and contamination survey meters, portabie neutron monitors, facility area, process and criticality nonitors, continuous-air monitors, air samplers, analytical equipment, portal monitors and hand and show monitors, and environmenta? radiation monitors. Simjlar instrumentation may be available from other manufacturers not listed in these tables. No information under a specification for an instrument means that no data was available in the instrument catalog for that specification and the manufacturer did not cffer the information. All instrument specifications 
IABLE 6.10. General Instrument Types, Applications, and Measurement Ranges

Instrument Type

A. Sample Analys is

(Analysis of wipe and air filter samples)

B. Portable survey meters (Determination of $B, Y$, neutron dose rate and $\alpha, \beta^{-}, \gamma$ surface contamination)

$\stackrel{\omega}{\infty}$

C. Fixed monitoring/alarming (Determination of criticality events and abnormal radiation levels in an area)
Applications

1) Gamma spectroscopy systems

2) Gas flow counters for $\alpha, \beta^{-}, \gamma$

3) Liquid scintillation counters for low energy $B$

1) Small volume $\left(<50 \mathrm{~cm}^{3}\right)$ ion chambers, mostly nonpressurized for high-rate $\gamma$ fields

2) Medium-volume jon chambers for mixed $\beta^{-} / Y$ radiations

3) Thin window GMS for contamination surveys

4) Gamma insensitive neutron rate meters.

1) Multiple ion chamber systems for criticality monitoring ( 2 of $\mathrm{N}$ system, where minimum of 2 detector trips required for alam)

2) Single ion chamber, GM, or scintillating detector for other external $y$ field alarming situations

3) Constant-flow air samplers for $\alpha, \beta^{-}, \gamma$ airborne contaminants

4) Passive criticality monitors for postaccident evaluation (require laboratory evaluation).
Measurement Ranges

Few $n C i$ to several nIC level. Sample dependent upon background and geometry.

$0-2.0 \times 10^{4} \mathrm{R} / \mathrm{hr}$

$0-5.0 \times 10^{5} \mathrm{cpm}\left\langle B^{-}, \gamma\right\rangle$

$0-2.0 \times 10^{6} \mathrm{cpm}(\alpha)$

$0-8.0 \times 10^{5} \mathrm{cpm}$

(neutron)

$0-10^{4} \mathrm{R} / \mathrm{hr}$

$0-10^{5} \mu \mathrm{Ci} / \mathrm{CC}$

adjustable alarms with

local and remote, visual

and audible alarms 
listed were obtained from specific vendors or from published catalogs. No attempt was made to verify the manufacturers' specifications or test the instruments.

\subsection{FUTURE INSTRUMENTATION NEEDS OF NRC/NMSS LICENSEES}

The future instrumentation needs of NRC/NMSS licensees as seen by the manufacturers and vendors and to what extent the manufacturers and vendors expect to meet those needs is discussed in this section. Part of the questionnaire sent to different manufacturers attempted to determine the vendors' attitudes regarding design changes in instrumentation in response to changing monitoring needs.

The following is a list sumarizing the responses of the manufacturers and vendors regarding the future instrumentation needs of NRC/NMSS Iicensees:

- solid state detectors and computerization

- higher qualjty and more versatile systems using the Tatest microprecessor technology

- greater use of low-level measurement equipment

- instrumentation with greater reliability and shorter response times

- in-plant electronic repair facilities

- measurement of specific isotopes for more accurate monitoring.

The following is a list summarizing the responses of the manufacturers and vendors regarding the methods and instrumentation they plan to provide to meet the future needs of IRC/NMSS licensees:

- addition of criticality monitors to present systems

- jntroduction of a new line of monitors using cadmium telluride

- improvements and modification of existing systems to make them more adaptable to various needs

- introduction of a single station area monitor with a wide dynamic range, low and high alarms (audible and visual), battery standby, reference source and remote caljbration features

- introduction of solid state neutron detectors to replace scintillation, GM and other detectors for criticality monitoring

- introduction of large-area proportional detectors with micro-computer control as a new generation of high-sensitivity contamination monitors

- introduction of new instruments for measuring working levels of radon daughters in air. 


\subsection{CONCLUSIONS}

The information obtained on the commercial instrumentation currently availabie to MMSS ijcensees and other users was obtained through a questior:riaire sent to manufacturers and vendors and by a review of commercial justrument catalogs. The information obtained was not intended to be all inclusive but should be considered to be from a thorough cross-section of manufacturers and venoors.

The capabilities of the instruments currently available and in use at NMSS 7 icense $s$ appear to be adequate for monitoring accident conditions. In general, the problems identified in the site visits were liinor and pertained to the use and maintenance of emergency instrumentation and not inadequacies of the instruments.

The responses of the manufacturers and vendors regarding the future instrumentation needs of NRC/NMSS 1 icensees and the methods by which they will be met show that: 1) there are some manufacturers that are sensitive to or at least knowledgeable of NRC/NMSS requirements arid future iceds, and 2) that some manufacturers plan to improve or modify existing systems or to introduce completely new systems to meet those needs. Mos c of the improvements involve the incorporation of computerized systeris for data analysis and control or new types of detectors 


\section{REFERENCES}

ANSI. 1969. Guide to Sampling Airborne Radionactive Materials in Nuclear Facilities. ANSI N13.1-1969. American National Standards Institute, New York, New York.

ANSI. 1972. Perfornance Specifications for Direct Reading and Indirect Reading Pocket Dosimeters for $X$ - and Gamma-Radiation. ANSI N13.5-1972. American National Standards Institute, New York, New York.

ANSI. 1977. Specification of Portable X-or Gamma-Radiation Survey Instruments. ANSI N13.4-1977. American Nationa? Standards Institute, New York, New York.

ANSI. 1978a. Calibration and Usage of Germanium Detectors for Measurement of Gamma-ray Emission of Radionuclides. ANSI N42.14. American National Standards Institute, New York, New York.

ANSI. 1978b. Radiation Protection Instrumentation Test and Calibration. ANS I N323-1978. American National Standards Institute, New York, New York.

ANSI. 1979. Performance Specifications for Reactor Emergency Radiological Monitoring Instrumentation. ANSI N320-1979. American National Standards Institute, New York, New York.

ANSI. 1980a. Calibration and Usage of Sodium Iodide Detector Systems. ANSI N42.12-1980. American Nationa? Standards Institute, New York, New York.

ANSI. 1980b. Performance Criteria for Instrumentation Used for In-plant Plutonium Monjtoring. ANSI N317-1980. American National Standards Institute, New York, New York.

ANSI. 1980c. Performance Verification of Liquid-scintillation Counting Systems. ANSI N42.15-1980. American National Standards Institute, New York, New York.

Andersen, B. V., et. ai. 1973. Technological Considerations in Emergency Instrumertation Preparedness, Phase II-B (Mixed Oxide Fuel Fabrication Facilities. BNWL-1742, Pacific Northwest Laboratory, Richland, Washington.

Andersen, E. V., et. al. 1974. Technological Considerations in Emergency Preparedness, Phase II-C, (FueT Reprocessing Facilities). BNwL-1957, Pacific Northwest Laboratory, Richland, Washingtor.

Bramson, P. E., et. a). 1974. Technological Considerations in Emergency Instrumentation Preparedness, Phase II-D (Evaluation, Testing and Calibration Methodology for Emergency Radiulogica? Instrumentation). BNWL-1991, Pacific Northwest Laboratory, Richland, Washington. 
Fish, H. R., ir. 1965. "Dosimetry and Instruments for Accident Situation Assessment." In Radiation Accidents and Emergencies in Medicine, Research, and Industry, L. H. Lanzl, J. H. Pingel and J. H. Rust (eds.), pp. 207-216. Chartes C. Thomas, springfield, Illinois.

Hooker, C. D. et al. 1983. Interim Calibration and Field Use Guidance for Beta Portable Survey Instruments. PNL-4378, Pacific Northwest Laboratory, Richland, Washington.

Keene, A. R., et al. 1963. "Elements of Engineering Planning for Coping with a Serious Radiation Accident." In Health Physics 9:793.

Kiefer, H. and R. Maushart. 1965. "Measurement in Successive Stages of an Emergency: Equipment, Methods, and Facilities." In Protection of the Public in the Event of Radiation Accidents, Proc. WHO Seminar, November 18-22, 1963, pp. 157-169. Hor!d Health Organization, Geneva.

Lahtj, G. P., et. al. 1980. Designing for Postaccident Radiological Conditions. Nuclear Safety Analys is Center Report NSAC-17, Electric Power Research Institute, Palo Alto, California.

McBride, J. A. and R. E. Cunningham. 1972. "The Role of Radiation Monitoring in Emergency Preparedness." In Health Physics Operational Monitoring, C. A. Willis and J. S. Handloser (eds.), Vol. III, p. 1439. Gordon and Breach, New York.

National Council on Radiation Protection and Measurements. 1978. Instrumentation and Monitoring Methods for Radiation Protection. NCRP Report 57, Washington, D.C.

National Council on Radiation Protection and Measurements. 1978. A Handbook of Radioactivity Measurements Procedures. NCRP Report 58, Washington, D.C.

Schmidt, G. D. 1978. "Interim Guidance on Offsite Emergency Monitoring Systems." IEEE Transactions on Nuclear Science NS-25(1):846.

Selby, J. M. and C. M. Unruh. 1971. Technological Considerations in Emergency Instrumentation Preparedness, Phase I (Current Capabilities Survey). BNWL-1552, Pacific Northwest Laboratory, Richland, Washington.

Selby, J. M., et. al. 1972. Technological Considerations in Emergency Instrumentation Preparedness, Phase II-A (Reactors). BNwL-1635, Pacific Northwest Laboratory, Richland, Washington.

U.S. Nuciear Regulatory Commission. 1979. Health Physics Surveys for Byproduct Materia] at NRC-Licensed Processing and Manufacturing Plants. Regulatory Guide 8.21, U.S. NRC, Washington, D.C.

U.S. Nuclear Reguiatory Commission. 1980a. Calibration and Error Limits of Air Sampling Instruments for Total Volume of Air Sampled. Regulatory Guide 8.25, U.S. NRC, Washington, D.C. 
U.S. Nuclear Regulatory Commission. 1980b. Criteria for Preparation and Evaluation of Radiological Emergency Response Plans and Preparedness in Support of Nuclear POwer Plants. NUREG-0654/FEMA-REP-1, Rev. 1, U.S. NRC, Washington, D.C.

U.S. Nuclear Regulatory Commission. 1981. Instrumentation for Light-waterCooled Nuciear Power Plants to Assess Plant and Environs Conditions During and Following an Accident. Regulatory Guide 1.97, U.S. NRC, Washington, D.C.. 

APPENDIX A

EXAMPLES OF SPECIFIC EQUIPMENT OBSERVED DURING SITE VISITS 
AFPENDIX A

EXAMPLES OF SPECIFIC EQLIIPMENT OBSERVED DURING SITE VISITS

CLASS I

Low-Volume Air Samplers for Gaseous Materials

1. Victoreen (08-030)

2. Eberline (RAP 1 or RAS 2)

3. RADECO (AVS-28)

High-Volume Air Sanplers for Particulate Materials

1. Johnson (ST-4)

2. Victoreen (08-600)

3. Eberline (RAP 1 or RAS 2)

4. RADECO (AVS-60)

Analytical Equipment

1. Baird, Canberra, and Tennelec Spectrometers riodification

2. Various analyzers usir. gas flow or sciritillatirig detectors

3. Medical dose calibrators

Eriticality Alarms

i. Nuclear Measurements (GA-3Bi)

Contamination Monitors

1. Technical Associates (PUG-1)

2. $\mathrm{NiCO}(\mathrm{MD}-3)$

3. Ludlun? $(3,28 \mathrm{~A})$

4. Nuclear Chicago (?)

5. Eberline (PAC-4G, 3A, 15)

Uigh-Range $\beta / \gamma$ Meters

1. Eberline (PIC-6A)

2. Victoreen (470A or 471A)

High-Range Neutron Kate Meter

1. Victoreen (488A)

2. Eberiline (PRS-2P/NRD) 


\section{CLASS II}

Portable Air Samplers

1. Eberitine (RAP 1 or RAS 1)

2. RADECO (AVS-28 or AVS-60)

\section{Fixed-Alarm Air Samplers}

1. Victoreen "XenAlert"

2. Triton (133C) (Xenon Monitor)

3. Triton (955B)

4. Ichnson (TR-5)

5. RADECO (GM-222)

Coritamination Monitors

1. Baird (904-122)

2. Johnson (GSM-10) (RML-3)

3. Ludlum (12) (14C)

4. DCA (3007)

5. Victoreen (493) (496) (491) (498)

6. Eberline (E120) (E120E) (520)

High-Range Rate Meter

1. Eberline $(\mu I C-6 \mathrm{~A})$

2. Victoreen (740A) or (471A)

Analytical Equipment

1. Various analyzers with gas flow or scintillating detectors

2. Medical dose calibrators

\section{CLASS III}

Low-Volume Air Sampling (low-flow rate pumps for bubbler system)

1. Eberline (RAS 1) (RAS 10)

2. Victoreen $(08-430)$

Personal air sampler

Alarming Air Samplers

1. Johnson (TR-5)

2. Triton (955B) 
Contamination Monitors (excepl $H=3$ )

1. Baird (904-122)

2. Johnson (GSM-10) (RML-3)

3. Ludlum (12) (14)

4. DCA (3007)

5. Victoreen (493) (496) (491) (498)

6. Ebertine $(E-120)(E-120 E)(E 520)$

Analytical Equipment

1. Liquid scintillation counters

2. Gas flow detector and counter

CLASS IV

High-Rate Monitors

1. Eberline PIC-6A

2. Victoreen (470A) (471A)

Low-Range Survey Meters

1. Ludium (19)

2. Eberline (PRM-7)

Analytical Equipment

1. Gas flow or scintillating detector and analyzer 

APPENDIX B

QUEST IONAAIRE SENT TO

VENDORS AND MANUFACTURERS 


\section{QUESTIONNAIRE}

The following questions pertain to instrumentation capable of monitoring radiological conditions during accidents at NMSS-Ticensed facilities.

1. What instruments do you currently have available that are adequate to monitor and measure accident radiological conditions? Please send specifications of instruments that measure beta/gamma dose rate fields and surface contamination. Also of interest are instruments for the collection and analys is of airborne activity, diarming effluent and area monitors, and criticality monitors.

2. Do you forsee any changes in the monitoring needs of materiais facilities in the future?

3. In the near future, does your company have pians to develop and market any new lines of equipment in response to changes in monitoring needs?

4. If so, please provide information (specifications) on any significant instrument development or modification underway at this time to meet projected needs.

5. How are instrument specifications determined (e.g., determined through testing or theoretically derived)?

6. What supplemental sources (exclusive of factor specifications) on instrument performance and operation are available to the customers?

7. Are operating instructions for emergency and high-level use provided with your equipment?

8. Are your instruments calibrated at your facility or elsewhere? 

NUREG CR-2499

PNL-4163

\section{DISTRIBUTION}

No. of

Copies

OFFSITE

U.S. Nuclear Regulatory Commission

Division of Technical

Information and Document Controt

7920 Norfolk Avenue

Bethesda, MD 20014

20 J. T. Long

U.S. Nuclear Regulatory Commission

Washington, D.C. 20555
No. of

Copies

ONSITE

24 Pacific Northwest Laboratory

T. H. Essig

W. N. Herrington (5)

G. R. Hoenes

J. D. Jamison

R. L. Kathren (5)

J. L. Kenoyer

M. A. Mckinney

J. M. Selby

E. C. Watson

Publishing Coordination PC (2)

Technical Information (5) 



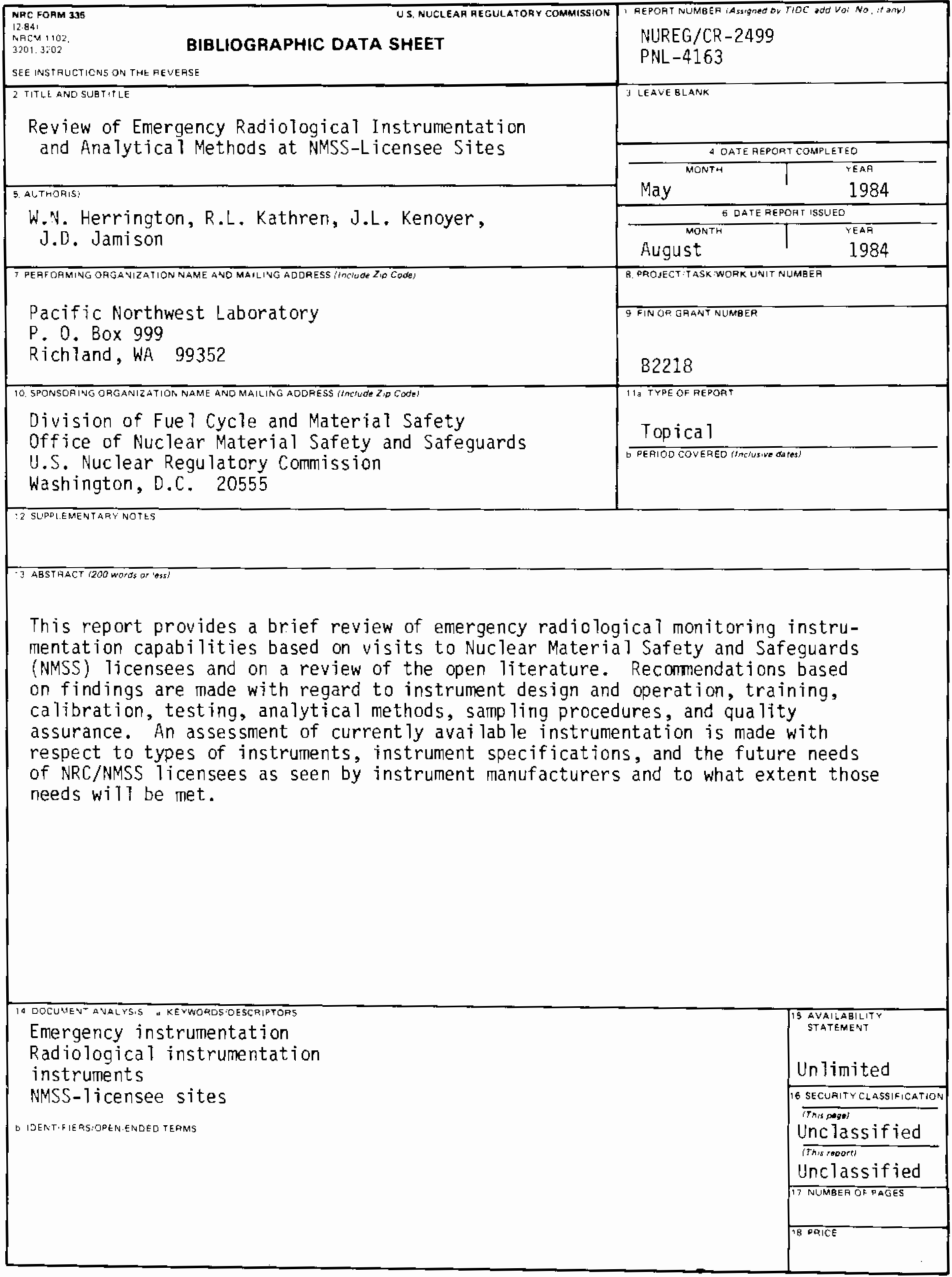


